\author{
Universidade de São Paulo \\ Faculdade de Economia, Administração e Contabilidade de \\ Ribeirão Preto \\ Departamento de Economia \\ Programa de Pós-graduação em Economia \\ Área: Economia Aplicada
}

\title{
Is manufacturing still the engine of growth? A multi sector analysis with a common correlated effects approach
}

Caíque Ferreira Silva

Supervisor: Prof. Dr. Sérgio Kannebley Júnior

Ribeirão Preto 
Prof. Dr. Vahan Agopyan

Reitor da Universidade de São Paulo

Prof. Dr. André Lucirton Costa

Diretor da Faculdade de Economia, Administração e Contabilidade de Ribeirão Preto

Prof. Dr. Sérgio Kannebley Júnior

Chefe do Departamento de Economia

Prof. Dr. Luciano Nakabashi

Coordenador do Programa de Pós-Graduação em Economia Aplicada 
Caíque Ferreira Silva

\title{
Is manufacturing still the engine of growth? A multi sector analysis with a common correlated effects approach
}

\author{
Dissertação apresentada ao Programa de \\ Pós-Graduação em Economia - Área de Con- \\ centração: Economia Aplicada, da Faculdade \\ de Economia, Administração e Contabilidade \\ de Ribeirão Preto da Universidade de São \\ Paulo, para obtenção do título de Mestre em \\ Ciências Econômicas.
}

Universidade of São Paulo - USP

Supervisor: Prof. Dr. Sérgio Kannebley Júnior

Ribeirão Preto

2021 
Autorizo a reprodução e divulgação total ou parcial deste trabalho, por qualquer meio convencional ou eletrônico, para fins de estudo e pesquisa, desde que citada a fonte.

\section{Ficha Catalográfica}

\section{Caíque Ferreira Silva}

Is manufacturing still the engine of growth? A multi sector analysis with a common correlated effects approach - Ribeirão Preto, 2021 52 p. : il.; $30 \mathrm{~cm}$.

Supervisor: Prof. Dr. Sérgio Kannebley Júnior

Dissertação de Mestrado - Universidade of São Paulo - Faculdade de Economia, Admnistração e Contabilidade - FEA/USP - Campus Ribeirão Preto; Departamento de Economia

Programa de Pós-Graduação em Economia; Área de Concentração: Economia Aplicada, 2021.

1. Modelo de Crescimento. 2. Efeitos Comuns Correlacionados. 3. Painel Dinâmico 4. Manufatura e Crescimento Econômico.

I. Orientador: Prof. Dr. Sérgio Kannebley Júnior.

II. Universidade of São Paulo - USP - Campus Ribeirão Preto. III. Faculdade de Economia, Administração e Contabilidade. IV. Is manufacturing still the engine of growth? A multi sector analysis with a common correlated effects approach 


\section{Acknowledgements}

I would like to express my gratitude to my master's colleagues, with whom I could absorb a significant amount of the necessary knowledge to do this work.

I also want to thank my advisor, Sérgio Kannebley Júnior, whose help was of great value.

Finally, I thank my parents, without whom my dreams would never be accomplished. 


\section{Abstract}

Since the middle of the twentieth century manufacturing has been assumed as an engine of economic growth and development. Nevertheless, the most recent literature has been pointing to other sectors, such as services, as the locus of productivity gains. This dissertation work access the role of manufacturing in the economic growth in 41 developed and developing countries between 1960 and 2010, adding services and two of its sub-sectors into the analysis. We propose the Common Correlated Effects method, developed by Pesaran (2006), for both static and dynamic panels, finding that these effects are present in the data. Moreover, the results indicate that manufacturing is indeed an engine of growth in the static panel data models, but have no growth impact with the dynamic panel approach.

Title: Is manufacturing still the engine of growth? A multi sector analysis with a common correlated effects approach.

Keywords: Growth Model. Common Correlated Effects. Dynamic Panel. Manufacturing and Economic Growth.

JEL: O10. O14. O40. 


\section{Resumo}

Desde meados do Século XX, a manufatura foi considerada um motor do crescimento e desenvolvimento econômicos. No entanto, a literatura mais recente tem apontado para o papel de outros setores, como o de serviços, na origem de ganhos de produtividade. $\mathrm{O}$ presente trabalho de dissertação trata do papel da manufatura no crescimento econômico em 41 países desenvolvidos e em desenvolvimento entre 1960 e 2010, adicionando o setor de serviços e dois de seus subsetores à análise. Propomos o método de Efeitos Comuns Correlacionados, desenvolvido por Pesaran (2006), para painéis estáticos e dinâmicos, verificando que esses efeitos estão presentes nos dados. Ademais, os resultados indicam que a manufatura é um motor de crescimento nos modelos estáticos, mas não tem efeito no crescimento para os modelos de painel dinâmico.

Título: A manufatura ainda é um motor do crescimento? Uma análise multi setorial com metodologia de efeitos comuns correlacionados.

Palavras-chave: Modelo de Crescimento. Efeitos Comuns Correlacionados. Painel Dinâmico. Manufatura e Crescimento Econômico.

JEL: O10. O14. O40. 


\section{List of Figures}

Figure 1 - Heterogeneity across countries and years of the GDP per capita growth 28

Figure 2 - Heterogeneity across countries and years of the manufacturing shares in GDP . . . . . . . . . . . . . . . . . . . . . . . . . . . . . . . . 29

Figure 3 - Heterogeneity across countries and years of the services shares in GDP 29

Figure 4 - Heterogeneity across countries and years of the finance, insurance, real state and business services shares in GDP . . . . . . . . . . . . 30

Figure 5 - Heterogeneity across countries and years of transport, storage and communication shares in GDP . . . . . . . . . . . . . . . . . . 30 


\section{List of Tables}

Table 1 - Variables' Labels . . . . . . . . . . . . . . . . . . . . 27

Table 2 - Descriptive Statistics of the Panel Data . . . . . . . . . . . . . 28

Table 3 - Fixed Effects \& Random Effects Results . . . . . . . . . . . . . . . . . 32

Table 4 - CCEMG \& CCEP Results . . . . . . . . . . . . . . . . . 33

Table 5 - CCEMG-r \& AMG Results . . . . . . . . . . . . . . . 34

Table 6 - FE Results - Dynamic Panel . . . . . . . . . . . . . . . 35

Table 7 - Long-Run Coefficients of the FE Models . . . . . . . . . . . . . . . 36

Table 8 - DCCE Results . . . . . . . . . . . . . . . . . 37

Table 9 - Long-Run Coefficients of the DCCE Models . . . . . . . . . . . . . 37

Table 10 - CCEMG \& CCEP Different Manufacturing Coefficients Between Groups of Countries . . . . . . . . . . . . . . . . . 38

Table 11 - CCEMG-r \& AMG Different Manufacturing Coefficients Between Groups of Countries . . . . . . . . . . . . . . . . . . 38

Table 12 - DCCE Different Manufacturing Coefficients Between Groups of Countries 38 Table 13 - CCEMG and CCEP Results for Developed Countries . . . . . . . . . . 47

Table 14 - CCEMG-r and AMG Results for Developed Countries . . . . . . . . . . 48

Table 15 - DCCE Results for Developed Countries . . . . . . . . . . . . . . . . . 49

Table 16 - CCEMG and CCEP Results for Developing Countries . . . . . . . . . . 50

Table 17 - CCEMG-r and AMG Results for Developing Countries . . . . . . . . . . 51

Table 18 - DCCE Results for Developing Countries . . . . . . . . . . . . . . 52 


\section{Contents}

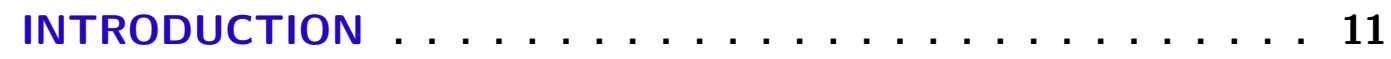

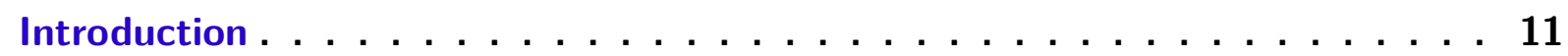

LITERATURE REVIEW . . . . . . . . . . . . . . . 13

Literature Review . . . . . . . . . . . . . . . . 13

2.1 The engine of growth hypothesis . . . . . . . . . . 13

$2.2 \quad$ Empirical evidence $\ldots \ldots \ldots \ldots \ldots \ldots$

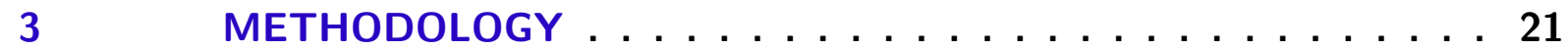

Methodology . . . . . . . . . . . . . . . . . 21

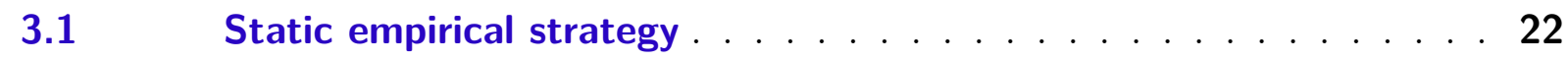

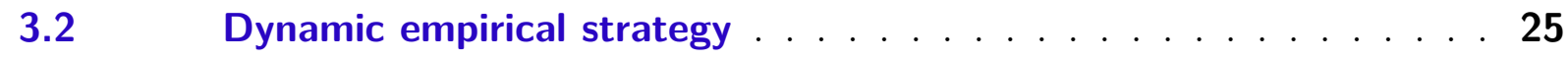

4 DATA AND VARIABLES $\ldots \ldots \ldots \ldots \ldots$

Data and Variables . . . . . . . . . . . . . . . . 27

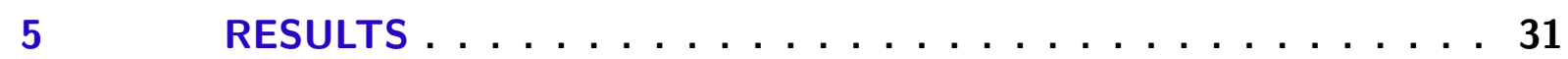

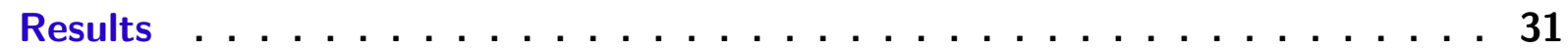

5.1 The "classic" panel data estimations . . . . . . . . . . 31

5.2 Common Correlated Effects estimations . . . . . . . . . . . 32

5.3 Dynamic panel models results . . . . . . . . . . . 35

5.4 Differences between developed and developing countries . . . . . . 37

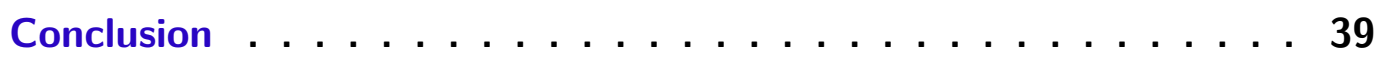

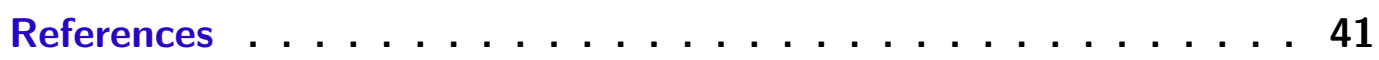

$\begin{array}{ll}\text { APPENDIX } & 46\end{array}$

APPENDIX A - CCE MODELS RESULTS FOR DEVELOPED COUN-

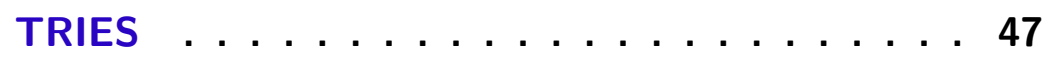


APPENDIX B - CCE MODELS RESULTS FOR DEVELOPING COUN-

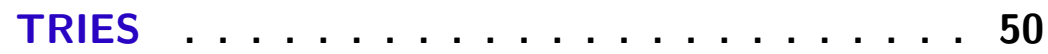




\section{Introduction}

The importance of the manufacturing sector in the development process has been observed by several authors in the economic growth literature, specially when we consider the articles from the twentieth century. More recently, with the deindustrialization process experienced by advanced countries and the productivity gains related to the services sector, the literature has shifted to an analysis that considers not only the manufacturing sector as the main driver of growth.

This research project aims to investigate the argument that relates manufacturing performance with economic growth, extending the analysis to a multi sector breakdown, as we also try to evaluate the impact of the services sector (and sub-sectors within services) throughout the development path. We propose to do so by using the Common Correlated Effects (CCE) method, developed by Pesaran (2006), in order to consider unobserved economic shocks that variate over time and are common to all the cross-section units. This method allows us to account for some unobserved effects (such as macroeconomic shocks, productivity shifts, structural changes, and so forth) that have been driving both economic growth and manufacturing sector shares and are common to all the countries in the database, with heterogeneous impacts and variation over time. This method also provides estimators with good properties when the data follows non-stationary processes.

The so called engine of growth argument stresses that manufacturing has a primary role as a driver of economic development, as Kaldor's first law, formulated by Kaldor (1966), states that the higher the manufacturing sector growth rate, the higher will be the rate of growth of the entire product of the economy. The kaldorian analysis points that the manufacturing sector induces growth because of some special characteristics of the sector, as they contribute to productivity growth in the entire economy by being the locus of technological change and by presenting opportunities for economies of scale, as well as by acting as the core through which knowledge and technology flows to the other sectors of the economy. The more recent literature argues that the technological intensive services sectors, such as software and financial markets, might also induce economic growth (CHAKRAVARTY; MITRA, 2009; INKLAAR; TIMMER; ARK, 2008; SZIRMAI, 2012; SZIRMAI; VERSPAGEN, 2015; TIMMER; DE VRIES, 2009; TRIPLETT; BOSWORTH, 2006).

Our primary research question is whether manufacturing has acted as an engine of growth in developed and developing countries or not. The hypothesis often analyzed in the literature is that manufacturing is one the drivers of economic growth, basically through the links between manufacturing and productivity. So the strategy proposed by 
our contribution is to test this hypothesis analysing a data set containing 41 countries (developed and developing) during the period of time between 1960 and 2010. As the importance of the services sector has been highlighted by the literature, we test the hypothesis of services and two sub-sectors within services being the engine of growth, as well. Basically, we are going to regress GDP per capita growth on the manufacturing shares in GDP (following SZIRMAI; VERSPAGEN, 2015) by constructing three different models: the first have manufacturing shares as the only variable of interest, the second adds services shares to the first model, and the third model adds the shares of two subsectors within services (finance, insurance, real state and business services; transport, storage and communication) to the first model. If the coefficient of the manufacturing shares variable is positive and statistically significant, that is evidence of the engine of growth argument.

The empirical strategy proposed uses the Common Correlated Effects (CCE) estimators developed by Pesaran (2006) and further extensions of these estimators (see BOND; EBERHARDT, 2013; CHUDIK; PESARAN, 2013), as all these estimators allow for cross-country data dependency. This approach controls for unobserved effects that change over time and are common to all the countries in the data set, which can be an important feature of the data when developing cross-country growth models. Given that the countries have interconnections through history, geography, trade relations, and so forth, it might be reasonable to take into account some possible dependency between countries when there is a shock driving both economic growth and economic sectors' performance. Moreover, this article also presents a dynamic session, as we propose a dynamic estimation approach (where the economic growth previous value impacts the economic growth present value), comparing the more traditional Fixed Effects estimations with the DCCE methodology presented by Chudik and Pesaran (2013). Finally, we propose an exercise comparing coefficients of developed countries and developing countries regressions.

The dissertation is structured as follows. The literature review is presented in the Chapter 2. Chapter 3 details the methodological approach. Chapter 4 presents the data and analyses the variables. The empirical results are presented in the Chapter 5. Chapter 6 concludes the work. 


\section{Literature Review}

\subsection{The engine of growth hypothesis}

Szirmai (2012) examines the engine of growth hypothesis and points that the literature argument for manufacturing acting as an engine of growth relies on the following arguments: opportunities for scale economies; demand and supply factors; structural change bonus and structural change burden; opportunities for capital accumulation; technological advance; linkage and spillover effects.

The argument that says that there is an empirical correlation between industrial activity and economic growth is related to the so called Kaldor's first law, formulated in a seminal article by Kaldor (1966). This law states that the faster the rate of growth of the manufacturing sector, the faster will be the rate of growth of the economy as a whole. The author, observing a sample data of twelve industrially advanced countries during the period between 1953 and 1963, firstly proposes a model regressing GDP growth rates on manufacturing production growth rates and later formalizes hypothesis to explain such relationship. More than finding a strong correlation between GDP growth and manufacturing growth, Kaldor points that his regression shows that the faster the overall rate of growth, the greater is the excess of the rate of growth of manufacturing production over the rate of growth of the entire economy. That is, if the manufacturing sector is growing more than the rest of the economy, the whole country tends to grow faster. However, Kaldor's lack of concern about the direction of the correlation that he finds might open his work to some criticism.

According to Kaldor (1966), the hypothesis that explain this relationship must be related to the behaviour of the productivity growth, as differences in the economic growth rate are often explained by differences in the productivity growth rate. Kaldor's link between productivity growth and manufacturing activities is the existence of economies of scale (or increasing returns), as he states that it is well-known that manufacturing is subject to increasing returns, because it can incorporate technological advance more easily than the primary and tertiary sectors, where the possibility for increasing returns are far more limited. Therefore, there is a relationship between the rate of growth of production and the rate of growth of productivity taking place in the manufacturing sector. The manufacturing activities are subjected to the so called Kaldor-Verdoorn law, that is, the production growth induces the productivity growth, and because of that feature, manufacturing is considered the engine of economic growth in Kaldor's article.

Observing the sample data of twelve countries during the period between 1953 
and 1963 once again, Kaldor regresses productivity growth rate on manufacturing output growth rate and on manufacturing employment, finding positive coefficients that supports the Kaldor-Verdoorn law. Nevertheless, the author provides little evidence to support that the direction of the causality is really that one proposed previously. A recent article by Marconi, Reis, and Araújo (2016) provides empirical evidence for the existence of the Kaldor-Verdoorn law, as well. Though, Szirmai (2012) addresses that services sector might also present economies of scale, specially after 1990, with the rising of information and communication technologies.

Cornwall (1977) sees the manufacturing sector as the locus of embodied and disembodied technological progress, as it is originated in manufacturing and diffuses to other sectors. Embodied technological advance, which is associated with capital accumulation, is the fact that new generations of capital goods embody the latest technology. Disembodied technological progress are improvements in technical knowledge that allow more output to be obtained from given inputs without the need to invest in new equipment. Although, services sector markets like the financial sector, software, retail sales, and distribution are also important drivers of information and communication technology progress (SZIRMAI, 2012).

Kaldor's reasons for the differences in the manufacturing production growth rates between some countries relies partly on demand factors and partly on supply factors. In the demand side, there are three sources of growth, the first being consumption, as the author arguments that a high income elasticity for manufacturing goods is characteristic of an intermediate income zone, one that takes place when the country is experiencing industrialization. So, as per capita income increases, it is assumed that the demand for primary products decreases, while the demand for manufacturing products increases (the Engel's law). Syrquin (1988) confirms this trend in developing countries, but some other works suggest that demand for services sector products might also increase during the development path (FALVEY; GEMMEL, 1996; ISCAN, 2010). The second and most important source of growth is capital investment. Kaldor (1966) addresses that a highly developed industrial sector supplies the goods that the own sector are going to invest, as the investments are made buying the products of the capital goods industry. Therefore, an expansion of the investments goods industry's productive capacity feeds the demand for its own products and the industry impacts the economic growth until it reaches the technological constraint. The third and final demand factor is net exports, as a country firstly becomes an importer of capital goods to initiate the industrialization, then turns a net exporter of manufacturing consumption goods, until it reaches the final stage of accelerated growth, when the country becomes a net exporter of capital goods.

The supply side can interrupt or decelerate the growth process because of two main reasons, commodities and labor, as Kaldor (1966) gives examples of countries that 
experienced a growth break-up. First, as the industrial sector is growing, it absorbs great amounts of commodities produced by other sectors. Analysing a typical economy of the early Twentieth century, Kaldor explains that sometimes this demand is absorbed by imports that can increase faster than the exports, causing a balance of payments constraint. The labor problem exists because the industrial growth generates demands for various kinds of services and its related work of force. However, the productivity growth induced by the manufacturing sector growth might not be enough, and it might be required an unfeasible amount of workers for the economic growth to continue to happen.

The structural change bonus argument assumes that the manufacturing sector is more productive than the agricultural sector, as some works have presented evidence (SYRQUIN, 1988; SZIRMAI, 2012). Therefore, as the economy industrializes and experiences an increase in manufacturing activity and a decrease in agricultural activity, the resources moves from a low to a high productivity sector. This creates a structural change bonus, as productivity increases in the economy as a whole and it induces economic growth. This argument is related to the two-sector growth models, the first being the Lewis model, formulated by Lewis (1954), which addresses the importance of transfers of resources from low to high productivity activities during the process of economic development. Other two-sector models, like the contributions of Ranis and Fei (1961) and Jorgenson (1961), are modifications of the Lewis model, as the first views the agricultural sector as an important source of growth and the second presents a neo-classical approach. Similar to the Lewis model, both also implies some transference of resources from low to high productivity activities throughout the path of development.

A structural change burden happens when the resources of one economy are transferred from high to low productivity sectors. According to Baumol (1967), this is what happens when services sector activity increases while manufacturing activity decreases. The Baumol's law states that GDP per capita growth will tend to slow down as the share of services in GDP increases. However, this argument have been contested in several recent works. Triplett and Bosworth (2006) argument that the "Baumol's Disease has been cured", as multifactor productivity in the services industries had an unprecedented acceleration in the United States after 1995. The authors also point that labor productivity growth in the services sector was as fast as in the rest of the economy. Inklaar, Timmer, and Ark (2008) presents a new database containing European countries, while analysing labor productivity in the services markets. The authors address that services is one the sectors that uses new technologies (ICT, in particular) and skilled work most intensively, and that leaded to increases in productivity growth rates across Europe and in the United States. For Timmer and De Vries (2009), growth accelerations are more explained by productivity increases within sectors than by labor relocation between sectors, as increases in services sector productivity contributed more than productivity gains in manufacturing to explain economic growth accelerations in developing countries. Chakravarty and Mitra 
(2009) argument that services sub-sectors such as transports, communication and banking induces growth by being the economy's physical and financial infrastructure. They point that services, construction and manufacturing have been the most important sources of growth in India.

Kaldor (1961) formalized a model where capital accumulation is not only one of the sources of economic development, but also a channel through which some other sources affect growth. Szirmai and Verspagen (2015) summarize that capital accumulation is more easily achieved in manufacturing, as the returns to capital (in terms of labour productivity and total factor productivity) are higher in the more spatially concentrated manufacturing than in the more spatially dispersed agriculture. Szirmai (2012) presents evidence of capital accumulation being more pronounced in manufacturing in developing countries.

When some non-primary economic activity induces the domestic production to supply the inputs for that activity, there is a backward linkage effect. The forward linkage effect happens when some activity not directed to final demand induces the use of its outputs as inputs in other activities. Both of these effects are associated with more investment and production and are presumed to be stronger on manufacturing (CORNWALL, 1977; HIRSCHMAN, 1958). Spillover effects are the disembodied knowledge flows between sectors, and it's assumed that technology generated in manufacturing flows to agriculture and services (CORNWALL, 1977; PARK; CHAN, 1989), generating productivity increases in the whole economy.

\subsection{Empirical evidence}

According to Szirmai (2012), the effects of manufacturing on growth can be measured by two different ways. One is using growth accounting techniques, which analyses what proportion of a given GDP growth rate derives from growth of manufacturing. The second technique is econometric analysis, in a way that structure a model to observe the empiric relationship between manufacturing performance and economic growth. The hypothesis often analyzed in the literature is that the manufacturing sector is one of the drivers of economic growth, basically through the links between the sector and productivity, as seen in the previous section.

The literature have shown mixed evidence about the engine of growth hypothesis. Some articles have emphasized the importance of manufacturing as an engine of growth more in developing countries than in advanced ones, while the contribution of the services sector has increased in the latest. Authors have also found evidence of manufacturing being more important for economic growth between the fifties and seventies. Some other works have tried to present local analysis at some specific countries or regions, either 
supporting manufacturing as engine of growth or arguing that services sector have been important as well.

Initial contributions, observing a sample data from developed countries during the fifties and sixties, propose an OLS approach and find a positive and significant relationship between manufacturing growth and GDP growth (CRIPPS; TARLING, 1973; KALDOR, 1966; UNITED NATIONS, 1970). Since Cornwall (1977), there is a concern about a potential endogeneity problem when regressing GDP growth on manufacturing sector output growth. The author proposes a 2SLS approach with a simultaneous equation model in a cross-section data environment, which is followed by Pacheco-López and Thirlwall (2013). Both works' results support the engine of growth hypothesis, as the later also points that manufacturing growth might induce GDP growth not only through the increase of productivity, but through an expansion in exports as well.

As data from more countries, including developing ones, has become available, some works have tried to test the engine of growth hypothesis with larger samples. Fagerberg and Verspagen (1999) modify Cornwall's approach, as they try to tackle the potential endogeneity problem proposing an instrumental variable technique in a simultaneous equation model. The authors find that, for developed countries, manufacturing does not seem to be the engine of growth, while in countries during the process of industrialization (or developing countries), manufacturing seems to have higher effects on growth. Moreover, they address that the role as engine of growth has relocated to industries other than manufacturing, that are the electronics and other sectors characterized by a strong science base and large investments in R\&D (research and development). In another paper, Fagerberg and Verspagen (2002) try to access the role of innovation and technological gaps in growth during three periods (1966-1972, 1973-1983 and 1984-1995), concluding that manufacturing has had a much more positive impact before 1973 than later. The approach is to use manufacturing shares of GDP as an explanatory variable for their growth model, choosing an OLS estimation technique.

Using industry as a proxy for modern economic activities, Rodrik (2009) doesn't distinguish industry from manufacturing. His method is to regress average growth rates of GDP for five year periods on corresponding averages of industrial share of GDP and industrial share of employment. The proposed technique uses panel data econometric methods, controlling for initial income levels and for countries fixed effects, so that it takes into account unobserved country characteristics that are constant over time. The author concludes that an expansion on both measures of industrial activity is closely associated with faster economic growth during the period of 1960 to 2004. And this relation is not weaker in lower-income countries, as the slope coefficient changes very little over different income ranges. Attiah (2019) also uses panel data econometric techniques, as he investigates the effects of manufacturing shares of GDP on economic growth and 
on growth acceleration. The author proposes fixed effects, random effects, and between estimators, and addresses that manufacturing has a positive effect on growth, and this effect is more pronounced for the less developed and higher educated countries; services sector appears to have no effects. When accounting for growth accelerations, the author concludes that manufacturing has a positive effect on growth acceleration, while services has a smaller but positive effect as well.

Szirmai and Verspagen (2015) extend the panel data techniques and use a method proposed by Hausman and Taylor $(1981)^{1}$ to regress average growth rates of GDP for five year periods on manufacturing shares of GDP at the beginning of each five year period. The authors observe a sample of developed and developing countries and their initial results indicate that manufacturing acts as an engine of growth with moderate effects. They also find that there are positive effects of manufacturing on growth in poorer countries with a highly educated workforce. That produces evidence for an extended version of the engine of growth hypothesis, which states that manufacturing is specially effective as a growth strategy at early phases of development, but also critically depends on absorption capability (represented by human capital in their model). Moreover, they address that, since 1990, manufacturing is becoming a more difficult path to growth than before, as greater amounts of human capital are required to achieve the same positive effects of manufacturing and the catching-up bonus seems to have become smaller. Another extension is made by Marconi, Reis, and Araújo (2016), as the authors use a dynamic panel model to investigate the two Kaldor's Laws, summarizing that manufacturing sector output growth is important to induce economic growth and productivity increases in middle-income countries. They also view manufacturing exports as a key for economic development. The contribution of Mercan, Kizllkaya, and Okde (2015) is one that proposes a method using the Common Correlated Effects (CCE) estimators. They investigate the Kaldor's Laws in ten newly industrial countries and find cross-section dependency between the developing countries, as well as non-stationarity of the GDP growth and manufacturing growth series. Their results corroborate the engine of growth hypothesis while controlling for potential common correlated effects, but are limited to a small sample.

At a local level, Kathuria and Natarajan (2013) tests whether if manufacturing growth impacts economic growth in India. With the same approach of Fagerberg and Verspagen (1999), they conclude that manufacturing has acted as an engine of growth, despite its declining in share of activity. Chakravarty and Mitra (2009) also investigate the engine of growth hypothesis in India, regressing economic growth on manufacturing growth with a vector auto-regression (VAR) framework. They produce evidence for a positive correlation between manufacturing and economic performance, but construction and

1 The Hausman-Taylor estimation technique can be seen as the random effects method, but assuming that some of the dependent variables are correlated with the country specific effect, and taking it into account by using instrumental variables. 
services might have been important for development in India as well. Jeon (2006) tests the Kaldor's Laws in China with time series and panel data econometric approaches, concluding that manufacturing indeed induces economic growth. Ndiaya and Lv (2018) investigate the role of industrialization on growth in Senegal, as they use time series methods to conclude that industry induces economic growth in the African country. Also for Africa, Keho (2018) analyses the validity of the first Kaldor's law in the Economic Community of West African States (ECOWAS) with panel data estimation methods, pointing that manufacturing causes economic growth and non-manufacturing output growth.

There is also some literature that utilizes growth account techniques instead of econometrics to investigate the engine of growth hypothesis. Such a method analyses what proportion of a given GDP growth rate derives from growth of manufacturing sector. Haraguchi, Cheng, and Smeets (2017) point that manufacturing remains an important driver of economic growth for developing countries over the last 20-25 years. They emphasize a continuously important role for the catching-up bonus, as low-income countries can take advantage by attracting industries from countries more industrialized to achieve economic growth. Timmer and De Vries (2009) observe a sample of countries in Asia and Latin America to go against Baumol's argument of structural change burden, as the authors point that market services and manufacturing are major contributors during economic growth acceleration, but the services sector appears to be the most important source.

We can overview the specification and econometric methods regarding engine of growth literature as follows. Since the initial contributions, there have been attempts to create specifications that can relate the manufacturing performance and the economic growth. The first authors simply regress the GDP growth on the manufacturing growth with a simple OLS approach, what might lead to an endogeneity problem, as GDP growth may determine and also be determined by manufacturing output growth. Later, the same specification is considered with a 2SLS model, which leads to a potential problem of weak instruments. Decades later, the IV approach is proposed to a similar specification and the problem of not suitable instruments still persists. The solution found, then, is to change the specification, using manufacturing shares in GDP as the explanatory variable, which is the proposition of our work. The first authors to do so, proposed a simple OLS technique, and we can argue that using the sector shares might not tackle the endogeneity problem entirely. Later, there is a methodology shift, as panel data techniques are proposed, as well as a new specification that regresses GDP growth between five years on manufacturing shares at the beginning of these five year periods. A lot of econometric methods are proposed, such as fixed and random effects, and between, as the endogeneity concern is present. The Hausman-Taylor model, which uses instruments, is proposed by a work and the concerns about the instrument variables still exist. In order to present better estimations while trying to control the problems of endogeneity without adding 
weak instruments, the Common Correlated Effects approach is proposed by a single author analysing a smaller sample size, as this model addresses the problem of common factors driving the data. The overall works' results don't variate much, in a way that the manufacturing activities appear to induce growth considering all these different methods.

As we can see, the literature regarding the engine of growth hypothesis shows mixed evidence, as it presents different conclusions at global and local levels. It also shows diverse interpretations on the mechanisms through which manufacturing induces economic growth. There are still some questions that can be formulated and answered in this topic, and our work is an attempt to do so, as we aim to extend the investigation with an estimation technique that controls for common correlated effects with a sample data containing a large number of countries. 


\section{Methodology}

Our primary research question is whether manufacturing has acted as an engine of growth in developed and developing countries or not. The strategy proposed by this contribution is to test the engine of growth hypothesis by analysing a data set containing 41 developed and developing countries considering a period of time between 1960 and 2010, focusing on the estimation of panel data models. We also add more economic sectors into the analysis, as the literature has shown evidence of sectors other than manufacturing being the locus of economic growth. The most important feature of our methodological approach, however, is the proposition of a new way of error treatment. We assume that our data is dependent in the form of common correlated effects, that is, there are time varying effects that impact all the countries in our data with different magnitudes. Moreover, we propose to treat this assumed feature of our data set with the CCE models of Pesaran (2006).

Our strategy is different from one that tests the Kaldor's Laws, as we do not regress manufacturing output on GDP growth or manufacturing productivity on overall productivity. Following the literature evolution, we begin the specifications with manufacturing (MAN) as the only variable of interest. Later, we address the assumed importance of the services sector (SER) by adding its shares in GDP. In order to have a more precise account on the role of services in economic growth, we substitute services shares by the shares of two sub-sectors within services, that is finance, insurance, real estate and business services (FIR), and transport, storage and communication (TSC). By doing so, we expect to target the markets that are assumed by the literature as some of the most productive in the economy, thus contributing more decisively for economic growth than services as a whole. The models also present control variables, assumed to be growth determinants. Our control variables are the same as in Szirmai and Verspagen (2015): human capital (HC); openness (OPEN), which is the sum of exports and imports shares in GDP; level of development (LEV), which is the GDP per capita related to the USA; and the logarithm of population (LNPOP). Basically, if the coefficient of the manufacturing share in GDP variable is positive and statistically significant, that is evidence of the engine of growth argument. Some of our work's important contributions to the literature of manufacturing as en engine of growth are the addition of the services sub-sectors into the model, as well as the proposition of a new estimation approach that considers common correlated effects driving the data, with both static and dynamic econometric models. Let's begin our empirical strategy with the static models. 


\subsection{Static empirical strategy}

Define the growth of GDP per capita in the $i$ th country between time periods $t$ and $t+1$ as $G R_{i t, i t+1}=\left(G R_{i t+1}-G R_{i t}\right) / G R_{i t}$. This yields the proposed base model (Model 1 ), considering a basic specification that was previously used in the literature, with MAN being the only sector share and HC, OPEN, LEV and LNPOP as the control variables, where the $\beta$ 's are the parameters that are going to be estimated.

$$
G R_{i t, i t+1}=\beta_{1} M A N_{i t}+\beta_{2} H C_{i t}+\beta_{3} O P E N_{i t}+\beta_{4} L E V_{i t}+\beta_{5} L N P O P_{i t}
$$

To start our theoretical discussion and the implementation of a common correlated effects (CCE) framework, consider the Model 1. Let $\mathbf{X}_{i t}$ be a $k \times 1$ vector of explanatory variables, so that $k=5$ and the rows of $\mathbf{X}_{i t}$ are the five explanatory variables (adding shares variables and controls is simply adding rows in $\mathbf{X}_{i t}$ ). We suppose that the data is generated by the following panel data model:

$$
G R_{i t, i t+1}=\boldsymbol{\alpha}_{i}{ }^{\prime} \mathbf{d}_{t}+\boldsymbol{\beta}_{i}{ }^{\prime} \mathbf{X}_{i t}+u_{i}+e_{i t}
$$

where $\mathbf{d}_{t}$ is a $n \times 1$ vector of observed common effects (including deterministics such as as intercepts or time dummies), $u_{i}$ is the unobserved time-invariant heterogeneities across the countries, and $e_{i t}$ is the unobserved and time-varying effect.

Several econometric methods were presented when we analysed the engine of growth literature. For a distinct environment, one that observes a cross section data set, strategies such as OLS, 2SLS and IV were used. Some other works present time series econometric methods, and, finally, there are authors analysing a panel data set with different strategies, such as random effects, fixed effects, between estimators, dynamic panels, and the CCE estimators proposed by our contribution (although, it was proposed in a work that only observed ten developing countries). The random effects estimation method assumes that both variable and invariable unobserved effects are not correlated with the explanatory variables $\left(\mathbf{d}_{t}, \mathbf{X}_{i t}\right)$, while the fixed effects estimator let the invariable effect $u_{i}$ be correlated with $\left(\mathbf{d}_{t}, \mathbf{X}_{i t}\right)$, but also require no correlation between $e_{i t}$ and $\left(\mathbf{d}_{t}, \mathbf{X}_{i t}\right)$. If there is some type of correlation between the time-varying error term and the explanatory variables, the fixed effects estimator is biased. Other panel data methods presented in the engine of growth literature, such as between, Hausman-Taylor, and dynamic panels, don't attempt to treat a possible correlation between the time-varying unobserved factors and the regressors due to common correlated effects.

In our work, we suppose that there might be some type of dependence between the time-varying unobserved effects $e_{i t}$ and our variables of interest, so that the estimators 
presented above are biased. We assume that this type of data dependence happens due to unobserved common factors that varies over time, i.e., time-varying unobserved effects driving the sectors shares in GDP and GDP per capita growth and are common to all the countries in our data set. For example, exogenous economic shocks might influence manufacturing (and other sectors) shares through changes in productivity, demand effects, rearrangements in the supply-side such as technological spillovers, structural changes, and so forth. Macroeconomic shocks might influence sector shares substantially, as well. However, these shocks also impact economic performance directly, and they are common to all the countries (or impact the countries of a same region, but we are assuming that the it effects our entire data set) given its economic connections. This type of shocks will be referred as Common Correlated Effects, as they are assumed to be common to all the countries in our panel, as well as time-variant and unobserved. As summarized by Eberhardt and Teal (2011), the potential for this type of data dependency is particularly relevant in the context of cross-country growth and development analysis, given that the countries are interconnected by history, geography and trade-relations. The authors highlight the importance of methods robust to this type of data generating process. One of these methods is proposed by Pesaran (2006), an approach that takes the unobserved common correlated effects (CCE) driving the data into account. We propose a technique using Pesaran's CCE estimators to investigate the engine of growth hypothesis, while tackling the potential problem of cross-country dependency. To provide evidence for this type of cross-sectional dependency driving our sample data, we conduct the CD Test, provided by Pesaran (2004), for cross-sectional dependency on the residuals of the regressions.

To begin with the CCE strategy, let the errors have the multifactor structure

$$
e_{i t}=\gamma_{i}^{\prime} \mathbf{f}_{t}+\epsilon_{i t}
$$

in which $\mathbf{f}_{t}$ is the $m \times 1$ vector of unobserved common effects, and $\epsilon_{i t}$ are the specific or idiosyncratic errors, assumed to be independently distributed of $\left(\mathbf{d}_{t}, \mathbf{X}_{i t}\right)$. In general, however, the unobserved factors $\mathbf{f}_{t}$ could be correlated with $\left(\mathbf{d}_{t}, \mathbf{X}_{i t}\right)$, and the method presented by Pesaran (2006) allows for this possibility. Consider the following model for the individual specific regressors

$$
\mathbf{X}_{i t}=\mathbf{A}_{i}^{\prime} \mathbf{d}_{t}+\boldsymbol{\Gamma}_{t}^{\prime} \mathbf{f}_{t}+\mathbf{v}_{i t}
$$

where $\mathbf{A}_{i}$ and $\boldsymbol{\Gamma}_{t}$ are $n \times k$ and $m \times k$ factor loading matrices, with fixed components of $\mathbf{X}_{i t}$, distributed independently of the common effects and across $i$, but assumed to follow general covariance stationary processes. It is allowed for $Y_{i t}$ and $\mathbf{X}_{i t}$ to follow processes with unit roots and/or deterministic trends by allowing one or more of the common effects 
in $\mathbf{d}_{t}$ or $\mathbf{f}_{t}$ to have unit roots and/or deterministic trends. As pointed by Eberhardt and Teal (2011), the CCE estimators account for the presence of the unobserved common factors $\mathbf{f}_{t}$ implicitly by adding cross-section averages (average across all panel units in period $\mathrm{t}$ ) for the dependent and independent variables to the regression equation. In the Mean Group estimator (CCEMG), each of these cross-section averages is interacted with a country dummy, whereas in the Pooled estimator (CCEP), they are simply added to the country regression (in either case, the specification assures that coefficients on the implied common factors are allowed to differ across countries, which is equivalent to different $\gamma_{i}$ across $i$ ). First, we propose estimations with fixed effects and random effects, and then we suggest modelling with the CCE approach, estimating by both the CCEP and the CCEMG versions. If the results of the fixed/random effects estimators are substantially different from the results of the CCE estimators, that is interpreted as evidence for common correlated effects driving the data, as well as a potential bias of the more traditional panel data estimators.

These two estimators presented above are not the only that take the common correlated effects into account when analysing static panel data. We are also using the Augmented Mean Group (AMG) estimator, introduced by Bond and Eberhardt (2013), which is a modification of the CCEMG estimator, with macro production function estimation in mind. While the CCEMG estimation method treats the unobserved common factor $\mathbf{f}_{t}$ as a nuisance, something to be taken into account but not of particular interest for the empirical analysis, the AMG approach estimates the unobserved common factor, referring to it as the common dynamic process. It is collected in the first of the three steps of the AMG procedure, where a pooled regression model augmented with year dummies is estimated by first difference OLS, and the coefficients on the differenced year dummies are the common dynamic process, which represents an estimated cross-group average of the evolution of the unobserved common factor over time. The second step augments the group-specific regression with the estimated common dynamic process as an explicit variable (in our case). In the third and final step, the group-specific model parameters are averaged across the panel, just like in the CCEMG estimator.

In order to provide some statistical evidence for our assumption of common correlated effects driving our data set, we conduct the CD Test for cross-sectional dependence, as mentioned previously. By comparing the CD Test p-values of the different models, we expect to have results that indicate the presence of cross-sectional dependence in the more traditional models, as well as the dependence being taken into account by the CCE approach, in a way that this dependence might exist in the form of common correlated effects. If the results of the fixed/random effects estimators are substantially different from the results of the CCE estimators, that is interpreted as evidence for common correlated effects driving the data, as well as a potential bias of the more traditional panel data estimators. As pointed by De Hoyos and Sarafidis (2006), the CD Test is also valid for 
dynamic panels, as we conduct the test in the dynamic part of our work, as well.

\subsection{Dynamic empirical strategy}

Now we consider a possible relationship between the GDP growth past values and current values, so that a dynamic process of adjustment to lung run equilibrium might be required, with an inclusion of a lagged dependent variable into the analysis. In order to address this question, we need to establish a dynamic panel empirical strategy. First of all, consider the same variables presented in Table 1 to begin with our dynamic panel model. As above, let $X_{i t}$ be the vector of explanatory variables and suppose now that the data is generated by the following dynamic panel data model:

$$
G R_{i t, i t+1}=\boldsymbol{\alpha}_{i}{ }^{\prime} \mathbf{d}_{t}+\boldsymbol{\lambda}_{i} \mathbf{G R}_{i t-1, i t}+\boldsymbol{\beta}_{i}{ }^{\prime} \mathbf{X}_{i t}+u_{i}+e_{i t}
$$

where $\boldsymbol{\lambda}_{i}$ is the impact of the growth past value on the growth actual value. Considering what has been developed in the dynamic panel literature, we could think about the Generalized Method of Moments (GMM) estimators as one of the methods for our analysis. The GMM, tough, is required for panels with more cross-section groups than periods of time, as a large $\mathrm{T}$ leads to a large number of instruments and weak tests (Sargan test and Hansen test). The GMM addresses the problem of the Nickell bias (NICKELL, 1981) that arises from the estimation of dynamic panels with Fixed Effects, but as demonstrated by Nickell (1981), this bias tends to zero as the periods of time increase. Considering that our data set have a sufficiently large number of time periods, we can assume that the Nickell bias is approximately zero and estimate the dynamic panel with Fixed Effects, while also preventing GMM results with weak Sargan tests and Hansen tests.

The large $\mathrm{T}$ might prevent us from the Nickell bias when modeling with FE, but this estimator might also be biased in a context of cross-section dependency caused by common correlated effects, just like in the static panel analysis. Chudik and Pesaran (2013) point that the CCE estimators are consistent only in nondynamic panels, but the authors propose another CCE method that is suited for dynamic panels, the Dynamic Common Correlated Effects (DCCE) estimators. Considering the dynamic panel of the Equation 5, if the idiosyncratic error $e_{i t}$ is cross-sectionally dependent and $E\left(\boldsymbol{\lambda}_{i}\right)=\boldsymbol{\lambda}$ (the mean coefficient of the lagged dependent variable), the lagged dependent variable is no longer strictly exogenous and the CCE estimator is inconsistent. According to Chudik and Pesaran (2013), the CCE estimator becomes consistent if the maximum of $\sqrt[3]{T}$ lags of the cross section averages are added for both the dependent and the strictly exogenous 
variables, so that we estimate the following equation:

$$
G R_{i t, i t+1}=\boldsymbol{\alpha}_{i}{ }^{\prime} \mathbf{d}_{t}+\boldsymbol{\lambda}_{i} \mathbf{G R}_{i t-1, i t}+\boldsymbol{\beta}_{i}{ }^{\prime} \mathbf{X}_{i t}+\sum_{l=0}^{\sqrt[3]{T}} \boldsymbol{\delta}_{i l}{ }^{\prime} \overline{\boldsymbol{Z}}_{t-l}+u_{i}+e_{i t},
$$

where $\overline{\boldsymbol{Z}}_{t}=\left(\overline{\mathbf{G R}}_{t-1, t}, \overline{\mathbf{X}}_{t}\right)$. Define the coefficient $\boldsymbol{\pi}_{i}=\left(\boldsymbol{\lambda}_{i}, \boldsymbol{\beta}_{i}\right)$, then the DCCEMG estimators are

$$
\widehat{\pi}_{M G}=\frac{1}{N} \sum_{i=1}^{N} \widehat{\pi}_{i}
$$

The authors also considers a pooled version of the dynamic estimators, the DCCEP, where the cross-section averages are interacted with a country dummy (like in the static CCE estimators). Therefore, we propose FE estimations, and then a DCCE approach, comparing the results and the CD Test p-values, in order to identify the accuracy of our hypothesis of common correlated effects driving our data set in a dynamic panel methodology as well. 


\section{Data and Variables}

Our country level data set is constructed by observing a sample data containing 41 developed and developing countries during a time period between 1960 and 2010. The variables we need to construct our empirical model are the following: GDP per capita (to construct the growth variable, as well as the level of development variable), value added of four economic sectors (manufacturing; services; finance, insurance, real state and business services; transport, storage and communication), so that we can construct the shares in GDP, human capital, openness, and population. Table 1 presents the labels for the variables we are going to use in our estimations.

Table 1 - Variables' Labels

\begin{tabular}{|l|l|}
\hline GDP per capita & GR \\
\hline Manufacturing shares in GDP & MAN \\
\hline Services shares in GDP & SER \\
\hline Finance, insurance, real state and business services shares in GDP & FIR \\
\hline Transport, storage and communication shares in GDP & TSC \\
\hline Human capital & HC \\
\hline Openness & OPEN \\
\hline Level of development & LEV \\
\hline Logarithm of population & LNPOP \\
\hline
\end{tabular}

We collected the GDP per capita data at constant 2011 prices in US Dollars from the 2018 version of the Maddison Project Database (INKLAAR; JONG, et al., 2018). To construct the shares variables, we collected the sectors' output data from the The Groningen Growth and Development Centre (GGDC) 10-Sector Database (TIMMER; DE VRIES; DE VRIES, 2015), as it provides data of the value added of ten different economic sectors, as well as output data of the entire economy. For human capital, we are going to use a proxy, which is the human capital index of the Penn World Table database, presented by Feenstra, Inklaar, and Timmer (2015). This variable is constructed using the average years of schooling from Barro and Lee (2013) and Cohen and Leker (2014), as well as the assumed rate of return of education presented by Psacharopoulos (1994), as the author estimated Mincer equations from around the world. The openness variable is the summation of exports and imports shares in GDP, and this shares are also provided by the Penn World Table database. The final control variable, logarithm of population, was also constructed with data provided by the Penn World Table.

Some characteristics of our data set are presented below. Table 2 shows the descriptive statistics of the panel data, where T-bar is the average number of observations per country. Meanwhile, a larger between than within standard deviation indicates that 
the variation of the data is more pronounced between the countries than between the years within the countries.

Table 2 - Descriptive Statistics of the Panel Data

\begin{tabular}{|c|c|c|c|c|c|c|c|}
\hline \multirow[b]{2}{*}{ Variable } & \multirow[t]{2}{*}{ Mean } & \multicolumn{3}{|c|}{ Standard Deviation } & \multicolumn{3}{|c|}{ Observations } \\
\hline & & Overall & Between & Within & No. of obs. & No. of countries & T-bar \\
\hline GR & 0.026 & 0.042 & 0.016 & 0.039 & 2050 & 41 & 50 \\
\hline MAN & 0.175 & 0.071 & 0.062 & 0.038 & 1974 & 41 & 48.1 \\
\hline SER & 0.384 & 0.137 & 0.132 & 0.050 & 1974 & 41 & 48.1 \\
\hline FIR & 0.077 & 0.061 & 0.057 & 0.026 & 1974 & 41 & 48.1 \\
\hline TSC & 0.066 & 0.029 & 0.024 & 0.017 & 1974 & 41 & 48.1 \\
\hline $\mathrm{HC}$ & 2.053 & 0.649 & 0.564 & 0.333 & 2050 & 41 & 50 \\
\hline OPEN & 0.463 & 0.629 & 0.580 & 0.260 & 2050 & 41 & 50 \\
\hline LEV & 0.333 & 0.293 & 0.285 & 0.818 & 2050 & 41 & 50 \\
\hline LNPOP & 83.93 & 204.3 & 200.0 & 52.50 & 2050 & 41 & 50 \\
\hline
\end{tabular}

The descriptive statistics show that the GDP per capita growth rate mean is $2.6 \%$, while the variability between the years within the countries is more pronounced than the variability between the countries, as the overall standard deviation is larger than the previous ones. Regarding the sectors shares, the services shares in GDP mean is $38.4 \%$, the largest one and signifficantly bigger than the manufacturing share in GDP mean $(17.5 \%)$. Services have the most variation, as well, with a overall standard deviation of 0.137 . The variation between countries is larger than the variation between years within countries for all the sector shares in GDP.

Figure 1 shows the heterogeneity of the GDP per capita growth, presenting means for each country and each year. Pointing the different scales between the two graphs, we can observe that the year means have a larger variation than the country means, as the GDP per capita growth data have significant variation between both countries and years.
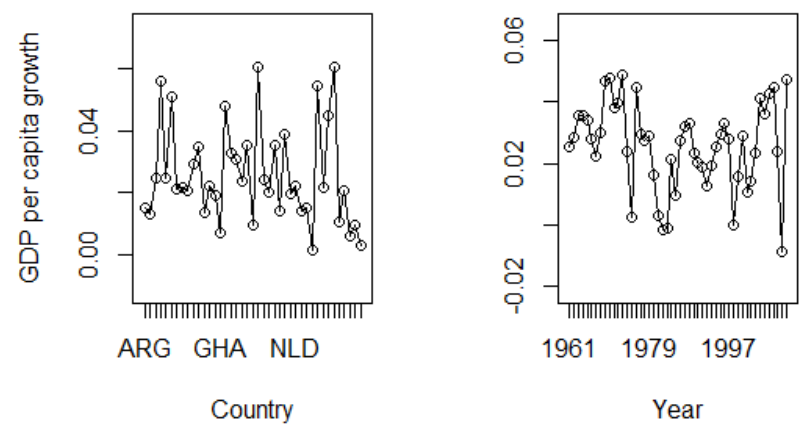

Figure 1 - Heterogeneity across countries and years of the GDP per capita growth

Figure 2 presents the country and year means of manufacturing shares in GDP. 
While the heterogeneity between countries is pretty strong, the year means show a trend in the first fifteen years of our data and a stabilization of the manufacturing shares after 1975, with some periods of increase and other of decrease over the years.
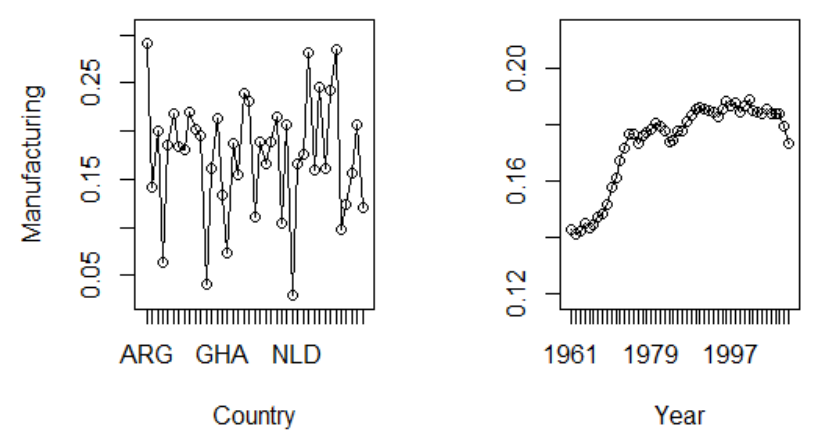

Figure 2 - Heterogeneity across countries and years of the manufacturing shares in GDP

The means of the services sector shares are presented in the Figure 3. The differences between countries are also strong regarding this sector, while there is a significant increase in the year means from around 1975 until 2010.
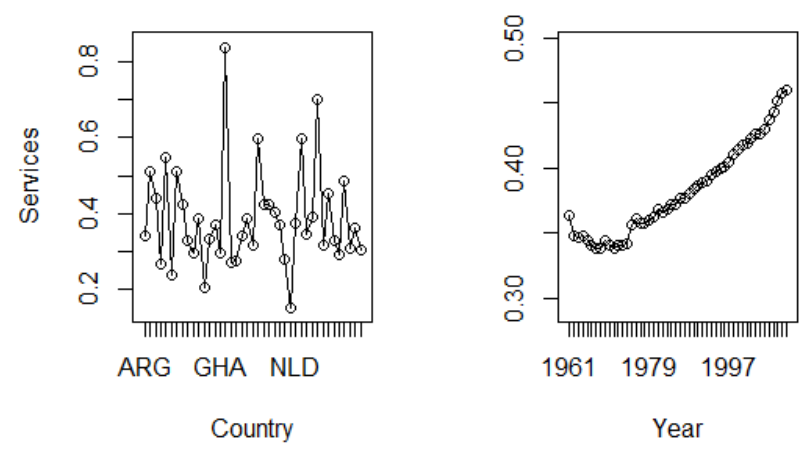

Figure 3 - Heterogeneity across countries and years of the services shares in GDP

Figure 4 and Figure 5 present the means of the services sub-sectors, while both finance, insurance, real state and business services shares and transport, storage and communication shares have a significant heterogeneity between the countries, while the year means plots show that both markets have had a great increase in shares after 1975 . 

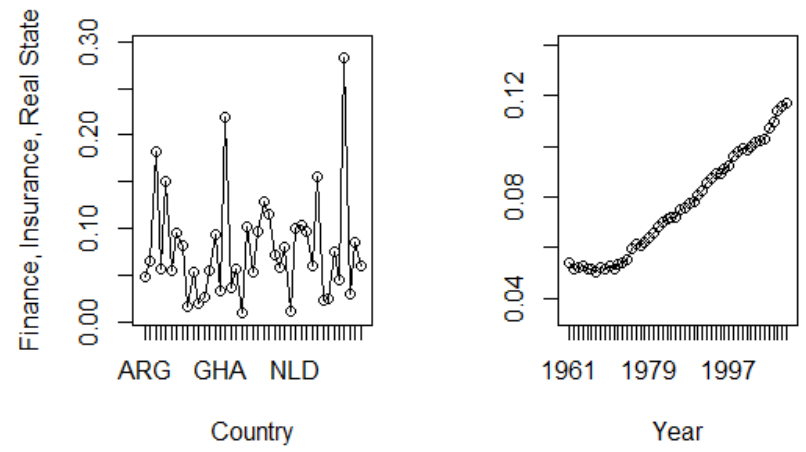

Figure 4 - Heterogeneity across countries and years of the finance, insurance, real state and business services shares in GDP
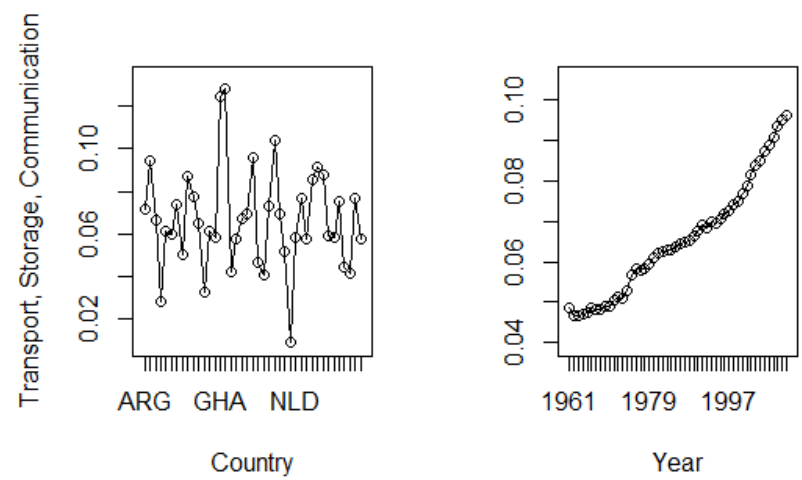

Figure 5 - Heterogeneity across countries and years of transport, storage and communication shares in GDP

Analysing the plots as a whole, we can observe a severe heterogeneity between the countries of our data set, as it contains high income, middle income and poor countries, with different economic characteristics. Moreover, the year means show that the GDP per capita growth means are also very heterogeneous across countries. The manufacturing sector shares have stable means after 1975, while the services shares and services sub-sectors shares have increasing means after 1975. After this analysis, the tentative conclusion is that the services sector as a whole has had more importance in the economies after 1975 until 2010, as the same is valid for the two sub-sectors within services that are assumed to be the most productive. 


\section{Results}

We present our estimation results by dividing between the more traditional panel data methods ( such as fixed effects and random effects), the CCE approach and its different models, and the dynamic panel method, where we compare traditional methods with the DCCE.

\subsection{The "classic" panel data estimations}

We begin presenting the results of the fixed effects (FE) and random effects (RE) models estimations, in Table 3. In the FE models, we control for time trends by adding time dummies for all but one year. The FE estimations, which controls for a fixed, time invariable effect that is different from country to country, suggest that manufacturing is an engine of growth in all of the three specifications, with coefficients around 0.06 and a significance level of $5 \%$, indicating that a $1 \%$ increase in the manufacturing share is associated with a 0.06 GDP per capita growth percent-point raise. Services and the financial sub-sector have not significant coefficients, while the communication market have a negative and significant coefficient at a $10 \%$ level. Level of development and logarithm of population are the only significant controls, all of them at $1 \%$. The results for the random effects (RE) models suggest that only the level of development and the intercept are significant at $1 \%$ as well.

The Hausman tests for the three models reject plain random effects as an appropriate model, so that the FE estimations are more accurate regarding our data set. The $\mathrm{CD}$ tests for all the $\mathrm{FE}$ and RE models have p-values that are close to zero, indicating that the residuals of the regression are correlated between cross section units, so that we might think about common correlated effects driving the data, something that has not been taken into account by the two classic panel data estimators. 
Table 3 - Fixed Effects \& Random Effects Results

\begin{tabular}{|c|c|c|c|c|c|c|c|c|c|c|c|c|}
\hline \multirow{3}{*}{$\begin{array}{l}\text { Dependent variable: GR } \\
\text { Variable }\end{array}$} & \multicolumn{4}{|c|}{ Model 1} & \multicolumn{4}{|c|}{ Model 2} & \multicolumn{4}{|c|}{ Model 3} \\
\hline & \multicolumn{2}{|c|}{$\mathrm{FE}$} & \multicolumn{2}{|c|}{$\mathrm{RE}$} & \multicolumn{2}{|c|}{$\mathrm{FE}$} & \multicolumn{2}{|c|}{$\mathrm{RE}$} & \multicolumn{2}{|c|}{$\mathrm{FE}$} & \multicolumn{2}{|c|}{$\mathrm{RE}$} \\
\hline & Coef. & SD & Coef. & SD & Coef. & SD & Coef. & SD & Coef. & SD & Coef. & SD \\
\hline MAN & $0.061^{* *}$ & 0.025 & 0.014 & 0.021 & $0.057^{* *}$ & 0.026 & 0.015 & 0.021 & $0.062^{* *}$ & 0.026 & 0.013 & 0.021 \\
\hline SER & & & & & -0.024 & 0.022 & 0.010 & 0.015 & & & & \\
\hline FIR & & & & & & & & & -0.006 & 0.051 & -0.028 & 0.032 \\
\hline TSC & & & & & & & & & 0.082 & 0.081 & $-0.115^{*}$ & 0.059 \\
\hline $\mathrm{HC}$ & -0.002 & 0.008 & 0.000 & 0.003 & -0.002 & 0.008 & -0.001 & 0.003 & -0.004 & 0.008 & 0.006 & 0.004 \\
\hline OPEN & 0.000 & 0.004 & 0.002 & 0.003 & 0.000 & 0.004 & 0.002 & 0.003 & 0.000 & 0.004 & 0.004 & 0.003 \\
\hline LEV & $-0.080^{* * *}$ & 0.012 & $-0.027 * * *$ & 0.008 & $-0.081^{* * *}$ & & $-0.026^{* * *}$ & 0.008 & $-0.079 * * *$ & 0.013 & $-0.032^{* * *}$ & 0.008 \\
\hline LNPOP & $0.022^{* * *}$ & 0.007 & 0.000 & 0.001 & $0.022^{* * *}$ & 0.007 & 0.000 & 0.002 & $0.022^{* *}$ & 0.007 & 0.000 & 0.008 \\
\hline Intercept & & & $0.032^{* * *}$ & 0.006 & & & $0.030^{* * *}$ & 0.007 & & & $0.031^{* * *}$ & 0.006 \\
\hline Time Dummies & Yes & & No & & Yes & & No & & Yes & & No & \\
\hline No. of obs. & 1974 & & 1974 & & 1974 & & 1974 & & 1974 & & 1974 & \\
\hline No. of countries & 41 & & 41 & & 41 & & 41 & & 41 & & 41 & \\
\hline Adjusted $\mathrm{R}^{2}$ & 0.129 & & 0.006 & & 0.130 & & 0.005 & & 0.129 & & 0.006 & \\
\hline Hausman test (p) & & 72.96 & $.000)$ & & & 73.64 & $.000)$ & & & 84.32 & $.000)$ & \\
\hline CD test $(\mathrm{p})$ & $-3.521(0$. & & $29.422(0$ & & $-3.529(0.0$ & & $29.368(0$. & 00) & $-3.547(0.0$ & & $29.250(0$ & 00) \\
\hline
\end{tabular}

\subsection{Common Correlated Effects estimations}

Now we present the results of the common correlated effects (CCE) estimations, an approach that controls for unobserved, time changing effects that are common to all the countries in our sample (with different impacts between the cross section units, tough). Table 4 shows the results of the CCEMG and CCEP estimators developed by Pesaran (2006). Regarding the CCEMG, Model 1 and Model 2 present positive and significant coefficients for manufacturing at 5\%, suggesting that a $1 \%$ manufacturing share increase raises growth by 0.4 percent-point according to Model 1 , and 0.6 percent-point according to Model 2 (the coefficient is not significant in the Model 3 though). The coefficients for services in Model 2 and its sub-sectors in Model 3 are non-significant at any level. When observing the control variables, the CCEMG estimates indicate a significance of both logarithm of population and level of development, as the later's coefficients have a very large magnitude ${ }^{1}$.

The CCEP estimations provide more parsimonious coefficients. Manufacturing shares are positive and significant in all the three models, with confidence levels of $95 \%$ in Model 1 and Model 3, and 99\% in Model 2; the magnitudes indicate that a 1\% manufacturing share increase raises growth by 0.1 percent-point in Model 1 and by 0.2 percent-point in Models 2 and 3. Services shares are positive and significant in the Model 2 with a 95\% confidence level, indicating that a $1 \%$ services share raise is associated with a 0.2 percentpoint increase in growth. The services sub-sectors are not significant in the Model 3. The significant coefficients of the control variables have expected signals considering all the models, with LEV presenting much smaller coefficients than the CCEMG estimates. Now we focus our analysis on the CD tests. All the p-values of the CCEMG models are larger than 0.05 , an indication that the CCEMG is being capable of treating the cross-sectionally

1 A 1 percentual-point increase of the GDP per capita related to the USA is related to more than a 3 percent-point GDP per capita growth decrease, which suggest a great importance of the stage of development for economic growth, as poorer countries tend to grow more than richer ones 
dependent residuals. The CCEP CD tests p-values are smaller than 0.05 though, indicating that these models fail to eliminate the residuals cross-section dependency. This results favor the argument for the existence of common correlated effects, as the CCEMG are taking those effects into account.

Table 4 - CCEMG \& CCEP Results

\begin{tabular}{|c|c|c|c|c|c|c|c|c|c|c|c|c|}
\hline \multirow{3}{*}{$\begin{array}{l}\text { Dependent variable: GR } \\
\text { Variable }\end{array}$} & \multicolumn{4}{|c|}{ Model 1} & \multicolumn{4}{|c|}{ Model 2} & \multicolumn{4}{|c|}{ Model 3} \\
\hline & \multicolumn{2}{|c|}{ CCEMG } & \multicolumn{2}{|c|}{ CCEP } & \multicolumn{2}{|c|}{ CCEMG } & \multicolumn{2}{|c|}{ CCEP } & \multicolumn{2}{|c|}{ CCEMG } & \multicolumn{2}{|c|}{ CCEP } \\
\hline & Coef. & SD & Coef. & $\mathrm{SD}$ & Coef. & $\mathrm{SD}$ & Coef. & $\mathrm{SD}$ & Coef. & $\mathrm{SD}$ & Coef. & $\mathrm{SD}$ \\
\hline MAN & $0.426^{* *}$ & 0.206 & $0.147^{* *}$ & 0.071 & $0.575^{* *}$ & 0.233 & $0.212^{* * *}$ & 0.075 & 0.353 & 0.261 & $0.222^{* *}$ & 0.090 \\
\hline SER & & & & & 0.203 & 0.149 & $0.182^{* *}$ & 0.060 & & & & \\
\hline FIR & & & & & & & & & -0.193 & 0.276 & 0.184 & 0.125 \\
\hline TSC & & & & & & & & & 1.026 & 0.760 & 0.139 & 0.208 \\
\hline $\mathrm{HC}$ & 0.074 & 0.193 & $0.101^{* * *}$ & 0.029 & 0.089 & 0.198 & $0.113^{* * *}$ & 0.030 & 0.169 & 0.192 & $0.082^{* *}$ & 0.042 \\
\hline OPEN & 0.029 & 0.051 & $0.020^{* * *}$ & 0.006 & 0.020 & 0.044 & $0.019^{* * *}$ & 0.006 & 0.036 & 0.047 & $0.025^{* * *}$ & 0.009 \\
\hline LEV & $-3.271^{* * *}$ & 0.635 & $-0.601 * * *$ & 0.054 & $-3.470^{* * *}$ & 0.676 & $-0.677^{* * *}$ & 0.057 & $-3.471^{* * *}$ & 0.622 & $-0.853^{* * *}$ & 0.067 \\
\hline LNPOP & $-0.545^{* *}$ & 0.248 & $-0.159^{*}$ & 0.084 & $-0.618^{* *}$ & 0.245 & $-0.271^{* * *}$ & 0.089 & $-0.949 * * *$ & 0.275 & -0.137 & 0.107 \\
\hline Intercept & 1.740 & 1.139 & $0.749^{* *}$ & 0.371 & 1.620 & 1.275 & $1.216^{* * *}$ & 0.467 & $2.333^{*}$ & 1.214 & $0.771^{*}$ & 0.431 \\
\hline No. of obs. & 1974 & & 1974 & & 1974 & & 1974 & & 1974 & & 1974 & \\
\hline No. of countries & 41 & & 41 & & 41 & & 41 & & 41 & & 41 & \\
\hline CD test $(p)$ & $0.285(0.7$ & & $3.107(0.0$ & & $0.347(0.7$ & & $2.932(0.0$ & & $1.833(0.0$ & & $2.724(0.0$ & \\
\hline
\end{tabular}

The CCEMG models appear to be a reasonable option, given the CD tests results. However, the huge magnitude of the LEV variable coefficients concerns us, as we might think that some outliers are pushing the mean of parameter coefficients to these high numbers. We remember that the CCEMG estimates an average of country specific coefficients, so that outliers might strongly impact the coefficients. The CCEP, a method that pools observations over the cross sectional units and avoid a great impact by outliers, presents normal LEV coefficients magnitudes, but it doesn't eliminate the problem of the cross-sectionally dependent errors. As pointed by Kapetanios and Pesaran (2005), pooling of observations over the cross section units create efficiency gains, but only when the individual slope coefficients are the same. In our case, we might suppose that the slope coefficients are different, given that the impacts of the common correlated effects in such distinct countries might not be very similar. This and the CD Tests results suggest that the CCEMG estimators are performing better for our analysis. Therefore, we propose CCEMG estimates with outlier-robust mean of parameter coefficients across countries. The robust CCEMG will be referred as CCEMG-r and its results are presented in the Table 5 together with the AMG estimates, as we refer to the common dynamic process as $\mathrm{C}$.

Regarding the CCEMG-r, the manufacturing share coefficients are positive and significant at a $95 \%$ confidence level in all the three models, with magnitudes of 0.4 in Models 1 and 2 and 0.5 in Model 3, in a way that a 1\% manufacturing share increase raises growth by around 0.4/0.5 percent-point. Services and its sub-sectors are not significant, while LEV and LNPOP are significant with expected signals, as LEV presents much smaller magnitudes than the CCEMG thanks to the outlier-robust nature of the CCEMG$\mathrm{r}$ (now, a 1 percent-point increase of the GDP per capita related to the USA is associated with a less than 2 percent-point decrease in growth). We maintain the outlier-robust 
mean of parameter coefficients across countries in the AMG estimations, as they also present positive and significant coefficients for Manufacturing in the three models, with a confidence level of 95\% in Model 1 and $99 \%$ in Models 2 and 3. The Model 1 and Model 2 coefficients indicate that an increase of $1 \%$ in manufacturing share in GDP raises growth by 0.3 percent-point, while for Model 3 a $1 \%$ manufacturing share increase induces growth by around 0.4 percent-point. Services have a positive and significant coefficient with a $90 \%$ confidence level, suggesting that a $1 \%$ increase in services share raises growth by 0.2 percent-point, an important feature that distinguishes the AMG. The LEV coefficients remain significant at a $99 \%$ confidence level, with expected signals and smaller magnitudes compared to the CCEMG-r. The common dynamic process coefficients are positive and significant at a $99 \%$ confidence considering all the three models ${ }^{2}$. The CD tests for all the CCEMG-r and AMG models just indicates the presence of common correlated effects, as well. The greater than $0.05 \mathrm{p}$-values allow us to argue that the CCE method is correcting the problem of residual cross-sectional dependency that arises from the common correlated effects.

Table 5 - CCEMG-r \& AMG Results

\begin{tabular}{|c|c|c|c|c|c|c|c|c|c|c|c|c|}
\hline \multirow{3}{*}{$\begin{array}{l}\text { Dependent variable: GR } \\
\text { Variable }\end{array}$} & \multicolumn{4}{|c|}{ Model 1} & \multicolumn{4}{|c|}{ Model 2} & \multicolumn{4}{|c|}{ Model 3} \\
\hline & \multicolumn{2}{|c|}{ CCEMG-r } & \multicolumn{2}{|c|}{ AMG } & \multicolumn{2}{|c|}{ CCEMG-r } & \multicolumn{2}{|c|}{ AMG } & \multicolumn{2}{|c|}{ CCEMG-r } & \multicolumn{2}{|c|}{ AMG } \\
\hline & Coef. & SD & Coef. & SD & Coef. & SD & Coef. & SD & Coef. & SD & Coef. & $\mathrm{SD}$ \\
\hline MAN & $0.380^{* *}$ & 0.184 & $0.304^{* *}$ & 0.130 & $0.424^{* *}$ & 0.216 & $0.328^{* * *}$ & 0.119 & $0.526^{* *}$ & 0.222 & $0.416^{* * *}$ & 0.147 \\
\hline SER & & & & & 0.213 & 0.134 & $0.191^{*}$ & 0.114 & & & & \\
\hline FIR & & & & & & & & & -0.169 & 0.272 & 0.111 & 0.213 \\
\hline TSC & & & & & & & & & 0.023 & 0.355 & -0.186 & 0.268 \\
\hline $\mathrm{HC}$ & 0.074 & 0.127 & $0.162^{*}$ & 0.084 & 0.115 & 0.147 & 0.110 & 0.085 & 0.100 & 0.166 & 0.023 & 0.079 \\
\hline OPEN & 0.018 & 0.035 & -0.004 & 0.038 & 0.026 & 0.034 & 0.001 & 0.038 & 0.048 & 0.030 & 0.015 & 0.036 \\
\hline LEV & $-1.554^{* * *}$ & 0.239 & $-1.327 * * *$ & 0.179 & $-1.709^{* * *}$ & 0.230 & $-1.305^{* * *}$ & 0.174 & $-1.876^{* * *}$ & 0.263 & $-1.280 * * *$ & 0.160 \\
\hline LNPOP & $-0.425^{* *}$ & 0.239 & $-0.344^{* *}$ & 0.158 & $-0.492^{* *}$ & 0.211 & $-0.409^{* *}$ & 0.178 & $-0.669^{* * *}$ & 0.232 & $0.283^{*}$ & 0.151 \\
\hline Intercept & 0.453 & 0.800 & 0.458 & 0.478 & 0.975 & 0.955 & 0.450 & 0.555 & 1.458 & 1.014 & 0.282 & 0.450 \\
\hline $\mathrm{C}$ & & & $0.970^{* * *}$ & 0.101 & & & $0.977 * * *$ & 0.098 & & & $0.965^{* * *}$ & 0.093 \\
\hline No. of obs. & 1974 & & 1974 & & 1974 & & 1974 & & 1974 & & 1974 & \\
\hline No. of countries & 41 & & 41 & & 41 & & 41 & & 41 & & 41 & \\
\hline CD test (p-value) & $0.285(0.7$ & & $1.230(0.2$ & & $0.347(0.72$ & & $1.276(0.2$ & & $1.833(0.0$ & & $1.321(0.18$ & \\
\hline
\end{tabular}

The CCE models results allow us to observe the relationship between manufacturing shares and economic growth, as well as other sectors shares and economic growth, more parsimoniously. Controlling for an assumed common correlated effect driving both explanatory and dependent variables, we obtained different results for the CD tests, so that we can argue that there might be effects driving both the sectors shares and/or the control variables and the GDP per capita growth, and the estimations presented by the FE and RE approaches might be biased, considering our sample. While controlling for common correlated effects and producing CD tests that indicate non cross-sectionally dependent residuals, almost every CCEMG model has positive and significant coefficients for manufacturing shares, as well as non significant coefficients for services and its subsectors. Thus, according to these results, we can argue that manufacturing has acted as

2 We remember that this variable is collected as follows: a pooled regression model augmented with year dummies is estimated by first difference OLS, and the coefficients on the (differenced) year dummies are collected. They represent an estimated cross-group average of the evolution of unobservable effect over time (see EBERHARDT; TEAL, 2011). 
the engine of growth considering our data set and assuming the occurrence of common correlated effects. The results for the services sector show little evidence of growth impact, as only the AMG presents a positive and significant coefficient (which is lower than the manufacturing one). Considering the services sub-sectors, there is no evidence of growth impact at all.

\subsection{Dynamic panel models results}

Now we begin the analysis considering a dynamic panel approach, where the lag of GDP per capita growth is included on each of the three proposed models. The number of lags of the dependent variable that we choose is one, given that the Arellano-Bond test for first-order - AR(1) - indicates first-order correlation and the test for second order - AR(2) - indicates no second-order correlation. Table 6 presents the FE results, where the GDP per capita growth lag is positive and significant in all the models. The coefficients of manufacturing shares are not significant, an important difference from the static panel models results. The Models 2 and 3 shows services and its sub-sectors with non significant coefficients, as well. The controls LEV and LNPOP have significant and small coefficients in the three different models, with population presenting a signal different from the expected. All the models also have non significant coefficients for $\mathrm{HC}$ and OPEN. The implied long-run coefficients are computed and reported in Table 7, using the Delta method to establish standard errors. The controls LEV and LNPOP continue to have significant estimates, as the magnitude of LEV is slightly smaller and the value of LNPOP is slightly larger. However, the CD tests p-values indicate cross-sectionally dependent residuals, and we can argue that common correlated effects might drive the data.

Table 6 - FE Results - Dynamic Panel

\begin{tabular}{|c|c|c|c|c|c|c|}
\hline \multirow{2}{*}{$\begin{array}{l}\text { Dependent variable: GR } \\
\text { Variable }\end{array}$} & \multicolumn{2}{|c|}{ Model 1} & \multicolumn{2}{|l|}{ Model 2} & \multicolumn{2}{|c|}{ Model 3} \\
\hline & Coef. & SD & Coef. & SD & Coef. & SD \\
\hline L_GR & $0.249^{* * *}$ & 0.041 & $0.248^{* * *}$ & 0.040 & $0.249^{* * *}$ & 0.040 \\
\hline MAN & 0.030 & 0.027 & 0.029 & 0.034 & 0.033 & 0.032 \\
\hline SER & & & -0.001 & 0.029 & & \\
\hline FIR & & & & & 0.020 & 0.056 \\
\hline TSC & & & & & 0.099 & 0.092 \\
\hline $\mathrm{HC}$ & 0.001 & 0.013 & 0.001 & 0.013 & -0.002 & 0.014 \\
\hline OPEN & 0.000 & 0.006 & 0.000 & 0.006 & 0.000 & 0.006 \\
\hline LEV & $-0.072^{* * *}$ & 0.023 & $-0.072^{* * *}$ & 0.023 & $-0.072^{* * *}$ & 0.021 \\
\hline LNPOP & $0.016^{*}$ & 0.009 & $0.016^{*}$ & 0.009 & $0.015^{*}$ & 0.008 \\
\hline No. of obs. & 1944 & & 1944 & & 1944 & \\
\hline No. of countries & 41 & & 41 & & 41 & \\
\hline Adjusted $\mathrm{R}^{2}$ & 0.068 & & 0.068 & & 0.067 & \\
\hline CD test ( $p$-value) & $-3.350(0.1$ & 01) & $-3.349(0$. & & $-3.369(0$. & \\
\hline
\end{tabular}


Table 7 - Long-Run Coefficients of the FE Models

\begin{tabular}{|c|c|c|c|c|c|c|}
\hline \multirow{2}{*}{$\begin{array}{l}\text { Dependent variable: GR } \\
\text { Variable }\end{array}$} & \multicolumn{2}{|c|}{ Model 1} & \multicolumn{2}{|l|}{ Model 2} & \multicolumn{2}{|c|}{ Model 3} \\
\hline & Coef. & SD & Coef. & SD & Coef. & SD \\
\hline MAN & 0.039 & 0.043 & 0.039 & 0.044 & 0.044 & 0.042 \\
\hline SER & & & -0.001 & 0.038 & & \\
\hline FIR & & & & & 0.026 & 0.074 \\
\hline TSC & & & & & 0.132 & 0.121 \\
\hline $\mathrm{HC}$ & 0.001 & 0.017 & 0.001 & 0.017 & -0.002 & 0.018 \\
\hline OPEN & 0.000 & 0.008 & 0.000 & 0.008 & 0.000 & 0.008 \\
\hline LEV & $-0.096 * * *$ & 0.031 & $-0.096^{* * *}$ & 0.031 & $-0.096 * * *$ & 0.029 \\
\hline LNPOP & $0.021^{*}$ & 0.011 & $0.021^{*}$ & 0.012 & $0.020^{*}$ & 0.011 \\
\hline
\end{tabular}

The Table 8 has the results for both DCCEMG and DCCEP estimation approaches, where common correlated effects are being taken into account in the dynamic panel. The DCCEP have significant (at a 1\% level) and positive coefficients for the lag of GR in all models, indicating that a 1 percent-point increase in GDP per capita growth in the previous year raises growth by 0.1 percent-point in the current year. Manufacturing share is significant and positive in all the models, as well, with magnitudes of $0.2,0.4$, and 0.3 for Models 1, 2, and 3, respectively. Model 2 also have positive and significant coefficients for services and Model 3 have positive and significant coefficients for the financial sector, and the significant control variables have expected signals. However, the CD tests for the three models indicate that the residuals have cross-sectional dependency, something similar do the CCEP models of the static panel. The CD tests results of the DCCEMG shows us the opposite, as the they indicate that the residuals for the three models aren't cross-sectionally dependent, so that the DCCEMG might be robust for the common correlated effects. Regarding its coefficients, the lag of GR is positive and significant at a $1 \%$ level in the three models, all of them suggesting that a 1 percent-point increase in GDP per capita growth in the previous year raises growth by 0.2 percent-point in the current year. However, manufacturing, services, and its sub-sectors appear to have effects on economic growth, according to these estimations. The control LEV is significant with large coefficients in the three models, while LNPOP is coefficient and have an expected signal only in Model 3. Table 9 have the imposed long-run coefficients for these models, where we have very similar coefficient magnitudes and significance, comparing to the short run results.

The dynamic panel approach gives us an alternative for analysing growth models, as the hypothesis of values from the previous year impacting the values from the actual period is a strong one. It also allows us to observe a long-run equilibrium for the estimated coefficients. This approach provided us some different results compared to the static panel data, as manufacturing lost its significance in the DCCEMG models, the ones that control for cross-section dependency. This important difference makes us look at the relationship 
between manufacturing and growth more parsimoniously. The static panel models provides evidence of manufacturing inducing growth, while dynamic panel models have shown that the lag of GDP per capita growth might be a more important variable related to current GDP per capita growth, as manufacturing lost its significance.

Table 8 - DCCE Results

\begin{tabular}{|c|c|c|c|c|c|c|c|c|c|c|c|c|}
\hline \multirow{3}{*}{$\begin{array}{l}\text { Dependent variable: GR } \\
\text { Variable }\end{array}$} & \multicolumn{4}{|c|}{ Model 1} & \multicolumn{4}{|c|}{ Model 2} & \multicolumn{4}{|c|}{ Model 3} \\
\hline & \multicolumn{2}{|c|}{ DCCEMG } & \multicolumn{2}{|c|}{ DCCEP } & \multicolumn{2}{|c|}{ DCCEMG } & \multicolumn{2}{|c|}{ DCCEP } & \multicolumn{2}{|c|}{ DCCEMG } & \multicolumn{2}{|c|}{ DCCEP } \\
\hline & Coef. & SD & Coef. & SD & Coef. & SD & Coef. & SD & Coef. & SD & Coef. & SD \\
\hline $\mathrm{L} \_\mathrm{GR}$ & $0.198^{* * *}$ & 0.039 & $0.098^{* * *}$ & 0.026 & $0.207^{* * *}$ & 0.041 & $0.109^{* * *}$ & 0.027 & $0.224^{* * *}$ & 0.047 & $0.139^{* * *}$ & 0.028 \\
\hline$\overline{M A N}$ & 0.190 & 0.242 & $0.181^{*}$ & 0.098 & 0.319 & 0.261 & $0.360^{* * *}$ & 0.102 & 0.170 & 0.289 & $0.292^{* *}$ & 0.124 \\
\hline SER & & & & & 0.215 & 0.180 & $0.365^{* * *}$ & 0.081 & & & & \\
\hline FIR & & & & & & & & & 0.200 & 0.350 & $0.349^{* *}$ & 0.163 \\
\hline TSC & & & & & & & & & 0.727 & 0.915 & 0.420 & 0.263 \\
\hline $\mathrm{HC}$ & 0.275 & 0.343 & $0.130^{* *}$ & 0.040 & 0.275 & 0.343 & $0.072^{*}$ & 0.041 & 0.088 & 0.532 & 0.045 & 0.060 \\
\hline OPEN & 0.028 & 0.047 & $0.035^{* * *}$ & 0.008 & 0.005 & 0.042 & $0.035^{* * *}$ & 0.008 & 0.026 & 0.037 & $0.041^{* * *}$ & 0.012 \\
\hline LEV & $-1.715^{*}$ & 0.912 & $-0.865^{* * *}$ & 0.072 & $-2.000^{*}$ & 1.037 & $-0.998^{* * *}$ & 0.077 & $-2.216^{* *}$ & 1.005 & $-1.273^{* * *}$ & 0.093 \\
\hline LNPOP & -0.465 & 0.591 & -0.069 & 0.115 & -0.816 & 0.586 & -0.190 & 0.123 & $-0.943^{* *}$ & 0.475 & 0.120 & 0.156 \\
\hline Intercept & 0.457 & 1.003 & $2.023^{* * *}$ & 0.740 & 0.215 & 1.149 & $1.341^{* *}$ & 0.582 & 0.939 & 1.452 & -0.325 & 0.569 \\
\hline No. of obs. & 1944 & & 1944 & & 1944 & & 1944 & & 1944 & & 1944 & \\
\hline No. of countries & 41 & & 41 & & 41 & & 41 & & 41 & & 41 & \\
\hline CD test $(p)$ & $1.05(0.29$ & & $-2.79(0.01)$ & & $1.79(0.07$ & & $-2.62(0.01)$ & & $1.76(0.08$ & & $-2.91(0.00$ & \\
\hline
\end{tabular}

Table 9 - Long-Run Coefficients of the DCCE Models

\begin{tabular}{|c|c|c|c|c|c|c|c|c|c|c|c|c|}
\hline Dependent variable: GR & & & el 1 & & & & el 2 & & & & el 3 & \\
\hline & DCC & MG & DCC & & $\mathrm{DCCl}$ & MG & $\mathrm{DCCH}$ & & DCCE & MG & $\mathrm{DCCH}$ & \\
\hline Variable & Coef. & $\mathrm{SD}$ & Coef. & $\mathrm{SD}$ & Coef. & SD & Coef. & SD & Coef. & $\mathrm{SD}$ & Coef. & SD \\
\hline MAN & 0.237 & 0.298 & $0.201^{*}$ & 0.109 & 0.403 & 0.324 & $0.404^{* * *}$ & 0.115 & 0.219 & 0.370 & $0.339^{* *}$ & 0.144 \\
\hline SER & & & & & 0.272 & 0.231 & $0.410^{* * *}$ & 0.094 & & & & \\
\hline FIR & & & & & & & & & 0.258 & 0.451 & $0.405^{* *}$ & 0.191 \\
\hline TSC & & & & & & & & & 0.936 & 1.190 & 0.489 & 0.308 \\
\hline $\mathrm{HC}$ & 0.342 & 0.433 & $0.145^{* * *}$ & 0.045 & 0.263 & 0.408 & $0.081^{*}$ & 0.046 & 0.113 & 0.685 & 0.053 & 0.070 \\
\hline OPEN & 0.035 & 0.058 & $0.039^{* * *}$ & 0.009 & 0.007 & 0.052 & $0.039^{* * *}$ & 0.010 & 0.033 & 0.048 & $0.048^{* * *}$ & 0.014 \\
\hline LEV & $-2.139 *$ & 1.132 & $-0.959^{* * *}$ & 0.090 & $-2.522^{*}$ & 1.311 & $-1.120^{* * *}$ & 0.101 & $-2.854^{* *}$ & 1.280 & $-1.479^{* * *}$ & 0.131 \\
\hline LNPOP & -0.580 & 0.738 & -0.077 & 0.128 & -1.029 & 0.744 & -0.213 & 0.128 & $-1.215^{* *}$ & 0.617 & 0.139 & 0.182 \\
\hline
\end{tabular}

\subsection{Differences between developed and developing countries}

In this section we propose an exercise of comparing the CCE models coefficients separating our data in two groups, developed and developing countries. Our data set contains 41 countries, 13 developed and 28 developing, nations with important economic differences but also similarities, specially when divided by these two groups. The complete results, including coefficients other than the manufacturing share in GDP one, as well as the CD Tests, are presented in the Appendix.

The Table 10 shows the manufacturing coefficients of the basic CCEMG and CCEP models. Regarding the CCEMG, the coefficients are significant at a 1\%, 5\%, or $10 \%$ level, except the Model 3 general coefficient. In terms of magnitudes, both grouped coefficients are larger than the general one, as manufacturing seems to impact growth slightly more substantially in developed countries than in developing ones, considering our data set. These results may suggest that the manufacturing sector is more productive in richer locations. 
Table 10 - CCEMG \& CCEP Different Manufacturing Coefficients Between Groups of Countries

\begin{tabular}{|c|c|c|c|c|c|c|c|c|c|c|c|c|}
\hline Dependent variable: GR & \multicolumn{4}{|c|}{ Model 1} & \multicolumn{4}{|c|}{ Model 2} & \multicolumn{4}{|c|}{ Model 3} \\
\hline \multirow[b]{2}{*}{ MAN Coefficient } & \multicolumn{2}{|c|}{ CCEMG } & \multicolumn{2}{|c|}{ CCEP } & \multicolumn{2}{|c|}{ CCEMG } & \multicolumn{2}{|c|}{ CCEP } & \multicolumn{2}{|c|}{ CCEMG } & \multicolumn{2}{|c|}{ CCEP } \\
\hline & Coef. & SD & Coef. & SD & Coef. & SD & Coef. & SD & Coef. & SD & Coef. & SD \\
\hline General & $0.426^{* *}$ & 0.206 & $0.147^{* *}$ & 0.071 & $0.575^{* *}$ & 0.233 & $0.212^{* * *}$ & 0.075 & 0.353 & 0.261 & $0.222^{* *}$ & 0.090 \\
\hline Developed Countries & $0.764^{* * *}$ & 0.246 & $0.215^{* * *}$ & 0.073 & $0.844^{* * *}$ & 0.310 & $0.317^{* * *}$ & 0.082 & $0.743^{* *}$ & 0.323 & $0.253^{* * *}$ & 0.092 \\
\hline Developing Countries & $0.514^{* *}$ & 0.247 & $0.256^{* *}$ & 0.117 & $0.670^{* *}$ & 0.318 & $0.227^{*}$ & 0.126 & $0.633^{* *}$ & 0.256 & $0.251^{*}$ & 0.135 \\
\hline
\end{tabular}

The coefficients comparison between countries for the robust CCEMG and AMG models are presented in the Table 11. The results are very similar to the previous CCEMG ones, as both developed and developing countries coefficients magnitudes are greater than the general ones, as well as the suggestion of manufacturing inducing growth more substantially in developed than developing countries. Moreover, 17 of the 18 coefficients are significant at a $1 \%, 5 \%$, or $10 \%$ level.

Table 11 - CCEMG-r \& AMG Different Manufacturing Coefficients Between Groups of Countries

\begin{tabular}{|c|c|c|c|c|c|c|c|c|c|c|c|c|}
\hline \multirow{3}{*}{$\begin{array}{l}\text { Dependent variable: GR } \\
\text { MAN Coefficient }\end{array}$} & \multicolumn{4}{|c|}{ Model 1} & \multicolumn{4}{|c|}{ Model 2} & \multicolumn{4}{|c|}{ Model 3} \\
\hline & \multicolumn{2}{|c|}{ CCEMG-r } & \multicolumn{2}{|c|}{ AMG } & \multicolumn{2}{|c|}{ CCEMG-r } & \multicolumn{2}{|c|}{ AMG } & \multicolumn{2}{|c|}{ CCEMG-r } & \multicolumn{2}{|c|}{ AMG } \\
\hline & Coef. & SD & Coef. & SD & Coef. & SD & Coef. & SD & Coef. & SD & Coef. & SD \\
\hline General & $0.380^{* *}$ & 0.184 & $0.304^{* *}$ & 0.130 & $0.424^{* *}$ & 0.216 & $0.328^{* * *}$ & 0.119 & $0.526^{* *}$ & 0.222 & $0.416^{* * *}$ & 0.147 \\
\hline Developed Countries & $0.647^{* * *}$ & 0.224 & $0.501^{* *}$ & 0.247 & $0.748^{* *}$ & 0.296 & $0.746^{* * *}$ & 0.218 & $0.773^{* *}$ & 0.365 & $0.763^{* * *}$ & 0.275 \\
\hline Developing Countries & $0.544^{* *}$ & 0.231 & $0.288^{*}$ & 0.159 & $0.454^{* *}$ & 0.197 & 0.187 & 0.164 & $0.542^{* *}$ & 0.240 & $0.317^{*}$ & 0.191 \\
\hline
\end{tabular}

The dynamic specification proposal shows models with more different coefficients, comparing to the previous static ones. No developing countries coefficients are significant, as only six of the 18 are significant at a 1\%,5\%, or 10\% level. The DCCEP Models 2 and 3 indicate that manufacturing induces growth more substantially in developed countries compared to the joint group. The DCCEMG Model 2 suggests that manufacturing is an engine of growth only when analysing developed countries separately. In general, this proposed exercise showed that separating the database between developed and developing countries produces different coefficients, giving interesting insights about the role of manufacturing in growth, as well as the different impacts in distinct income ranges. It is also important to observe the CD Test results, showed in the Appendix tables, in order to address whether this models take the common correlated effects into account or not.

Table 12 - DCCE Different Manufacturing Coefficients Between Groups of Countries

\begin{tabular}{|c|c|c|c|c|c|c|c|c|c|c|c|c|}
\hline Dependent variable: GR & \multicolumn{4}{|c|}{ Model 1} & \multicolumn{4}{|c|}{ Model 2} & \multicolumn{4}{|c|}{ Model 3} \\
\hline & \multicolumn{2}{|c|}{ DCCEMG } & \multicolumn{2}{|c|}{ DCCEP } & \multicolumn{2}{|c|}{ DCCEMG } & \multicolumn{2}{|c|}{ DCCEP } & \multicolumn{2}{|c|}{ DCCEMG } & \multicolumn{2}{|c|}{ DCCEP } \\
\hline MAN Coefficient & Coef. & $\mathrm{SD}$ & Coef. & $\mathrm{SD}$ & Coef. & SD & Coef. & SD & Coef. & $\mathrm{SD}$ & Coef. & SD \\
\hline General & 0.190 & 0.242 & $0.181^{*}$ & 0.098 & 0.319 & 0.261 & $0.360^{* * *}$ & 0.102 & 0.170 & 0.289 & $0.292^{* *}$ & 0.124 \\
\hline Developed Countries & 0.449 & 0.424 & 0.171 & 0.113 & $0.681^{*}$ & 0.371 & $0.524^{* * *}$ & 0.133 & 0.366 & 0.463 & $0.467^{* * *}$ & 0.152 \\
\hline Developing Countries & 0.068 & 0.306 & 0.148 & 0.154 & 0.159 & 0.375 & 0.215 & 0.164 & 0.122 & 0.332 & 0.275 & 0.183 \\
\hline
\end{tabular}




\section{Conclusion}

In this work, we addressed the argument of manufacturing as the engine of economic growth. We analysed the manufacturing shares in GDP and its relation with economic growth, while adding services shares and services sub-sectors shares (finance, insurance, real state and business services; transport, storage and communication) into the analysis. The panel data set contained 41 developed and developing countries for a period of time between 1960 and 2010. We regressed GDP per capita growth on manufacturing shares in GDP and a set of control variables, later adding services shares in GDP and services sub-sectors shares in GDP into the regressions. By doing so, we tried to test the hypothesis of manufacturing as a sector that induces economic development, as well as the role of services and services markets that are assumed to be high productive by the growth literature.

We utilised a empirical methodology with the common correlated effects (CCE) models, firstly proposed by Pesaran (2006) and then modified by some other authors (BOND; EBERHARDT, 2013; CHUDIK; PESARAN, 2013). This method produces estimates that take into account an unobserved effect that changes across time and is common to all the cross section units (while affecting these units differently), something that the more traditional random effects and fixed effects models don't do. We also propose two types of estimates, one is static and the other uses a dynamic panel, in order to consider a possible relationship between growth past values and current values, so that a dynamic process of adjustment to a long-run equilibrium is required. For both specification approaches, we compare the CCE models (DCCE in the dynamic case) with the classic FE and RE estimates, using the CD test for residual cross-sectional dependency proposed by Pesaran (2004).

In general, the hypothesis of common correlation effects driving the data when analysing the engine of growth argument is a reasonable one for our data set, considering our estimation, tests results. The different CD test values of the traditional estimates and the CCEMG method, both in the static and dynamic panel, are our main evidence for that conclusion. Considering the role of manufacturing on growth, we can argue that manufacturing has been an engine of growth in the countries analysed. We have little evidence for services and its sub-sectors affecting growth. However, in the long-run, the lagged dependent variable might be much more important than manufacturing in a dynamic panel environment.

Regarding the static models, the $\mathrm{CD}$ tests indicated that the FE and RE residuals were cross-sectionally dependent, while the the CCEMG and Augmented CCEMG (AMG) 
CD tests results did not indicate residual dependency. Therefore, we can argue that these models are taking common correlated effects into account, as the FE and RE estimates might be biased. The unbiased estimators (considering common correlated effects) presented positive and significant coefficients of manufacturing shares, indicating that it is an engine of growth in our data set (with magnitudes ranging between 0.1 and 0.5 , so that a $1 \%$ manufacturing share in GDP increase raises growth by 0.1 to 0.5 percent-point). However, the control variable level of development is far more important for economic growth, with larger coefficients magnitudes. Services appeared to have a positive relationship with growth (smaller than manufacturing) only in the AMG model, while the services sub-sectors did not have any significant coefficient. Therefore, the major importance of the manufacturing sector in comparison with services, first assumed by Kaldor, has been confirmed by our static panel analysis. All the CCEP CD tests indicated cross-sectionally dependent residuals, so that their estimates might still be biased, attesting the better quality of the CCEMG and AMG models, considering our environment.

The dynamic panel models also indicate cross-sectionally dependent residuals for the traditional FE estimates and the DCCEP. The DCCEMG presented sufficient large CD test p-values, so the models might be unbiased considering the common correlated effects with independent residuals. The DCCEMG estimates, however, showed non significant manufacturing shares coefficients, as well as no growth impact for services and its sub-sectors. The lagged dependent variable was significant in all the models. Thus, when trying to construct a dynamic process of adjustment to a long-run equilibrium, lagged growth values are far more important than sectors shares in GDP. The control variable level of development remained significant with a large magnitude, and the long-run coefficients had very similar values and significance. Hence the dynamic nature of growth, considering our data set, shows that the previous values are more important growth determinant than the manufacturing share, which has no impact at all, rejecting the Kaldor's hypothesis and being a counterpoint to the static models presented in this work. Finally, the comparison between developed and developing countries indicate that the manufacturing shares impacts growth more crucially in richer locations, although it is important to verify the models CD Test results.

Further extensions of our analysis might try to contemplate more countries into the data set, possibly separating developed from developing countries, as the literature shows that the different development stages might change the effects of manufacturing, services, and other sectors on economic growth. Another possible data extension is to include the more recent years into the analysis. The inclusion of manufacturing exports, as made by some other authors, can also be important, as well as other control variables that capture institutional characteristics. Finally, one might suggest utilising manufacturing growth rates instead of manufacturing shares in GDP, something that has also been proposed by other authors. 


\section{References}

ATTIAH, Eman. The Role of Manufacturing and Service Sectors in Economic Growth: An Empirical Study of Developing Countries. European Research Studies Journal, v. XXII, n. 1, p. 112-127, 2019.

BARRO, Robert J.; LEE, Jong-Wha. A new data set of educational attainment in the world, 1950-2010. Journal of Development Economics, v. 104, p. 184-198, 2013. ISSN 0304-3878. DOI: https://doi.org/10.1016/j.jdeveco.2012.10.001. Available from:

<http://www.sciencedirect.com/science/article/pii/S0304387812000855>.

BAUMOL, William J. Macroeconomics of Unbalanced Growth: The Anatomy of Urban Crisis. American Economic Review, v. 57, n. 3, p. 415-426, 1967. Available from: <http://piketty.pse.ens.fr/files/Baumol1967.pdf >.

BOND, Stephen; EBERHARDT, Markus. Accounting for unobserved heterogeneity in panel time series models. In:

CHAKRAVARTY, Sangeeta; MITRA, Arup. Is industry still the engine of growth? An econometric study of the organized sector employment in India. Journal of Policy Modeling, v. 31, n. 1, p. 22-35, 2009. ISSN 01618938. DOI:

10.1016/j.jpolmod.2008.06.002.

CHUDIK, Alexander; PESARAN, Mohammad Hashem. Large Panel Data Models with Cross-Sectional Dependence: A Survey. [S.l.], 2013. Available from: <http:

//www.dallasfed.org/assets/documents/institute/wpapers/2013/0153.pdf >.

COHEN, Daniel; LEKER, Laura. Health and Education: Another Look with the Proper Data. [S.l.], 2014. Available from:

<http://www . cepr.org/pubs/dps/DP9940.asp\%7B\%5C\%\%7D5Cnhttp:

//search. ebscohost. com/login. aspx?direct=true $\% 7 \mathrm{~B} \% 5 \mathrm{C} \& \% 7 \mathrm{Ddb}=\mathrm{ecn} \% 7 \mathrm{~B} \% 5 \mathrm{C} \&$ $\% 7 \mathrm{DAN}=1439271 \% 7 \mathrm{~B} \% 5 \mathrm{C} \& \%$ Dsite=ehost - live $\% 7 \mathrm{~B} \% 5 \mathrm{C} \& \%$ Dscope=site $>$.

CORNWALL, John. Modern Capitalism: It's Growth and Transformation. New York: St. Martin's Press, 1977.

CRIPPS, Francis; TARLING, Roger. Growth in Advanced Capitalist Economies, 1950-1970. Cambridge: Cambridge University Pres, 1973.

DE HOYOS, Rafael E.; SARAFIDIS, Vasilis. Testing for cross-sectional dependence in panel-data models. Stata Journal, v. 6, n. 4, p. 482-496, 2006. ISSN 1536867X. DOI: $10.1177 / 1536867 \times 0600600403$. 
EBERHARDT, Markus; TEAL, Francis. Econometrics for grumblers: A new look at the literature on cross-country growth empirics. Journal of Economic Surveys, v. 25, n. 1, p. 109-155, 2011. ISSN 09500804. DOI: 10.1111/j.1467-6419.2010.00624.x. FAGERBERG, Jan; VERSPAGEN, Bart. "Modern Capitalism" in the 1970s and 1980s by. In: GROWTH, Employment and Inflation. [S.l.: s.n.], 1999. P. 113-126.

. Technology-gaps, innovation-diffusion and transformation: an evolutionary interpretation. Research Policy, v. 31, p. 1291-1304, 2002.

FALVEY, Rodney E.; GEMMEL, Norman. Are services income-elastic? Some new evidence. The Review of Income and Wealth, v. 3, n. 42, p. 257-269, 1996. Available from: <https://doi.org/10.1111/j.1475-4991.1996.tb00182.x>. FEENSTRA, Robert C.; INKLAAR, Robert; TIMMER, Marcel P. The Next Generation of the Penn World: Version 8.0. American Economic Review, v. 105, n. 10, p. 3150-3182, 2015. Available from: <www.ggdc.net/pwt>.

HARAGUCHI, Nobuya; CHENG, Charles Fang Chin; SMEETS, Eveline. The Importance of Manufacturing in Economic Development: Has This Changed? World Development, Elsevier Ltd, v. 93, p. 293-315, 2017. ISSN 18735991. DOI: 10.1016/j.worlddev.2016.12.013. Available from: <http://dx.doi.org/10.1016/j.worlddev.2016.12.013>.

HAUSMAN, Jerry A.; TAYLOR, William E. Panel Data and Unobservable Individual Effects. Econometrica, v. 49, n. 6, p. 1377-1398, 1981.

HIRSCHMAN, Albert O. The Strategy of Economic Development. New Haven: Yale University Press, 1958.

INKLAAR, Robert; JONG, Harmen de, et al. Rebasing 'Maddison': new income comparisons and the shape of long-run economic development. [S.1.], 2018. Available from: <https://ideas.repec.org/p/gro/rugggd/gd-174.html>.

INKLAAR, Robert; TIMMER, Marcel P.; ARK, Bart van. Market services productivity across Europe and the US. Economic Policy, v. 23, n. 53, p. 140-194, 2008. Available from: <https://doi.org/10.1111/j.1468-0327.2007.00194.x>.

ISCAN, Talan. How Much Can Engel's Law and Baumol's Disease Explain the Rise of Service Employment in the United States? The B.E. Journal of Macroeconomics, v. 1, n. 10, 2010. Available from: <https://doi.org/10.2202/1935-1690.2001>. JEON, Yongbok. Manufacturing, Increasing Returns and Economic Development in China, 1979-2004: A Kaldorian Approach. [S.1.], 2006. Available from: <https://EconPapers.repec.org/RePEc:uta:papers :2006_08>.

JORGENSON, Dale W. The Development of a Dual Economy. The Economic Journal, v. 71, n. 281, p. 309-334, 1961. Available from: <https://www.jstor.org/stable/2228770>. 
KALDOR, Nicholas. Capital Accmulation and Economic Growth. In: THE Theory of Capital. London: Palgrave Macmillan, 1961. P. 177-222.

Causes of the slow rate of economic growth of the United Kingdom: an inaugural lecture. Cambridge: Cambridge University Press, 1966. P. 1-39.

KAPETANIOS, George; PESARAN, Mohammad Hashem. Alternative Approaches to Estimation and Inference in Large Multifactor Panels: Small Sample Results with an Application to Modelling of Asset Returns. The Refinement of Econometric Estimation and Test Procedures: Finite Sample and Asymptotic Analysis, June 2005. DOI: 10.1017/CB09780511493157.013.

KATHURIA, Vinish; NATARAJAN, Rajesh Raj. Is Manufacturing an Engine of Growth in India in the Post-Nineties? Journal of South Asian Development, v. 8, n. 3, p. 385-408, 2013. DOI: 10.1177/0973174113504849.

KEHO, Yaya. Manufacturing and Economic Growth in ECOWAS Countries: A Test of Kaldor's First Law. Modern Economy, v. 09, n. 05, p. 897-906, 2018. ISSN 2152-7245. DOI: 10.4236/me.2018.95057.

LEWIS, William Arthur. Economic Development with Unlimited Supplies of Labour. The Manchester School, v. 22, n. 2, p. 139-191, 1954. Available from: <https://doi.org/10.1111/j.1467-9957.1954.tb00021.x>.

MARCONI, Nelson; REIS, Cristina Fróes de Borja; ARAÚJO, Eliane Cristina de. Manufacturing and economic development: The actuality of Kaldor's first and second laws. Structural Change and Economic Dynamics, Elsevier B.V., v. 37, p. 75-89, 2016. ISSN 0954349X. DOI: 10.1016/j.strueco.2015.12.002. Available from: <http://dx.doi.org/10.1016/j.strueco.2015.12.002>.

MERCAN, Mehmet; KIZILKAYA, Oktay; OKDE, Burak. Are The Kaldor's Laws Valid? Panel Data Analysis under Cross Section Dependency for NIC Countries. Procedia Economics and Finance, v. 23, October 2014, p. 140-145, 2015. ISSN 22125671. DOI: 10.1016/s2212-5671(15)00399-8.

NDIAYA, Cisse; LV, Kangjuan. Role of Industrialization on Economic Growth: The Experience of Senegal (1960-2017). American Journal of Industrial and Business Management, v. 8, n. 10, p. 2072-2085, 2018. ISSN 2164-5167. DOI: 10.4236/ajibm.2018.810137.

NICKELL, Stephen. Biases in Dynamic Models with Fixed Effects. Econometrica, [Wiley, Econometric Society], v. 49, n. 6, p. 1417-1426, 1981. ISSN 00129682, 14680262. Available from: <http://www.jstor.org/stable/1911408>.

PACHECO-LÓPEZ, Penélope; THIRLWALL, A. P. A New Interpretation of Kaldor's First Growth Law for Open Developing Countries. Canterbury, 2013. 
PARK, Se Hark; CHAN, Kenneth S. A cross-country input-output analysis of intersectoral relationships between manufacturing and services and their employment implications. World Development, v. 17, n. 2, p. 199-212, 1989. ISSN 0305750X. DOI: $10.1016 / 0305-750 x$ (89)90245-3.

PESARAN, Mohammad Hashem. Estimation and Inference in Large Heterogeneous Panels with a Multifactor Error Structure. Econometrica, v. 74, n. 4, p. 967-1012, 2006.

General Diagnostic tests for Cross Section dependence in Panels. [S.l.], 2004.

PSACHAROPOULOS, George. Returns to investment in education: A global update. World Development, v. 22, n. 9, p. 1325-1343, 1994. ISSN 0305750X. DOI: 10.1016/0305-750X (94)90007-8.

RANIS, Gustav; FEI, John C. H. A Theory of Economic Development. American Economic Review, v. 51, n. 4, p. 533-565, 1961. DOI:

10.1057/978-1-349-95189-5_340. Available from:

<https://www.jstor.org/stable/1812785>.

RODRIK, Dani. Growth after the Crisis. [S.1.], 2009.

SYRQUIN, Moshe. Patterns of Structural Change. In: CHENERY, Hollis Burnley.; SRINIVASAN, Thirukodikaval Nilakanta (Eds.). Handbook of Development

Economics. [S.1.]: Elsevier Science Publishers B. V., 1988. v. I. Patterns o, p. 205-268. SZIRMAI, Adam. Industrialisation as an engine of growth in developing countries , 1950 - 2005. Structural Change and Economic Dynamics, Elsevier B.V., v. 23, n. 4, p. 406-420, 2012. ISSN 0954-349X. DOI: 10.1016/j.strueco.2011.01.005. Available from: <http://dx.doi.org/10.1016/j.strueco.2011.01.005>.

SZIRMAI, Adam; VERSPAGEN, Bart. Manufacturing and economic growth in developing countries, 1950 - 2005. Structural Change and Economic Dynamics, Elsevier B.V., v. 34, p. 46-59, 2015. ISSN 0954-349X. DOI:

10.1016/j.strueco.2015.06.002. Available from:

<http://dx.doi.org/10.1016/j.strueco.2015.06.002>.

TIMMER, Marcel; DE VRIES, Gaaitzen J. Structural change and growth accelerations in Asia and Latin America: a new sectoral data set. Cliometrica, v. 3, June (2), p. 165-190, 2009. DOI: 10.1007/s11698-008-0029-5.

TIMMER, Marcel; DE VRIES, Gaaitzen J.; DE VRIES, Klaas. Patterns of structural change in developing countries. Routledge Handbook of Industry and

Development, July, p. 65-83, 2015. DOI: 10.4324/9780203387061. 
TRIPLETT, Jack E.; BOSWORTH, Barry P. "Baumol's Disease" has been Cured: IT and Multifactor Productivity in US Service Industries. In: THE New Economy and Beyond. [S.l.]: Edward Elgar Publishing, 2006. chap. 3. Available from:

<https://EconPapers.repec.org/RePEc:elg:eechap:3965_3>.

UNITED NATIONS. Economic Survey of Europe 1969, Part 1. New York: United Nations, 1970. 
Appendix 


\section{APPENDIX A - CCE Models Results for Developed Countries}

Tables 13, 14, and 15 shows the complete developed countries model results, including the CD tests. The p-values suggest that the separation of the data changes the test results, as the residuals of the regression are not cross-sectionally dependent in only three specifications (AMG Model 1, DCCEMG Model 2, and DCCEMG Model 3). Hence all the other models have cross-sectionally dependent residuals and may not take into account the common correlated effects driving the data.

Table 13 - CCEMG and CCEP Results for Developed Countries

\begin{tabular}{|c|c|c|c|c|c|c|}
\hline Dep variable: GR & Mo & el 1 & Mod & el 2 & Mo & el 3 \\
\hline & CCEMG & CCEP & CCEMG & CCEP & CCEMG & CCEP \\
\hline MAN & $\begin{array}{l}0.764^{* * *} \\
(0.246)\end{array}$ & $\begin{array}{l}0.215^{* * *} \\
(0.0731)\end{array}$ & $\begin{array}{l}0.844^{* * *} \\
(0.310)\end{array}$ & $\begin{array}{l}0.317^{* * *} \\
(0.0819)\end{array}$ & $\begin{array}{l}0.743^{* *} \\
(0.323)\end{array}$ & $\begin{array}{l}0.253^{* * *} \\
(0.0917)\end{array}$ \\
\hline $\mathrm{HC}$ & $\begin{array}{l}0.489^{*} \\
(0.290)\end{array}$ & $\begin{array}{l}0.0524^{*} \\
(0.0283)\end{array}$ & $\begin{array}{l}0.662^{*} \\
(0.383)\end{array}$ & $\begin{array}{l}0.0762^{* * *} \\
(0.0286)\end{array}$ & $\begin{array}{l}0.717^{* *} \\
(0.344)\end{array}$ & $\begin{array}{l}0.0683^{* *} \\
(0.0334)\end{array}$ \\
\hline OPEN & $\begin{array}{l}-0.0633 \\
(0.0427)\end{array}$ & $\begin{array}{l}-0.00549 \\
(0.00784)\end{array}$ & $\begin{array}{l}-0.0866^{* *} \\
(0.0416)\end{array}$ & $\begin{array}{l}-0.0129 \\
(0.00836)\end{array}$ & $\begin{array}{l}-0.0386 \\
(0.0405)\end{array}$ & $\begin{array}{l}-0.0000858 \\
(0.00989)\end{array}$ \\
\hline RELUS & $\begin{array}{l}-0.724^{* * *} \\
(0.154)\end{array}$ & $\begin{array}{l}-0.260^{* * *} \\
(0.0432)\end{array}$ & $\begin{array}{l}-0.721^{* * *} \\
(0.138)\end{array}$ & $\begin{array}{l}-0.369^{* * *} \\
(0.0539)\end{array}$ & $\begin{array}{l}-0.911^{* * *} \\
(0.173)\end{array}$ & $\begin{array}{l}-0.364^{* * * *} \\
(0.0589)\end{array}$ \\
\hline LNPOP & $\begin{array}{l}-0.116 \\
(0.234)\end{array}$ & $\begin{array}{l}-0.0684 \\
(0.0727)\end{array}$ & $\begin{array}{l}0.00228 \\
(0.328)\end{array}$ & $\begin{array}{l}-0.125 \\
(0.0801)\end{array}$ & $\begin{array}{c}-0.0264 \\
(0.294)\end{array}$ & $\begin{array}{c}-0.0694 \\
(0.104)\end{array}$ \\
\hline SER & & & $\begin{array}{l}0.316^{*} \\
(0.185)\end{array}$ & $\begin{array}{l}0.272^{* * *} \\
(0.0849)\end{array}$ & & \\
\hline FIR & & & & & $\begin{array}{l}0.421 \\
(0.422)\end{array}$ & $\begin{array}{l}0.156 \\
(0.155)\end{array}$ \\
\hline TSC & & & & & $\begin{array}{l}-0.460 \\
(0.358)\end{array}$ & $\begin{array}{l}0.0290 \\
(0.233)\end{array}$ \\
\hline Intercept & $\begin{array}{c}-0.256 \\
(0.894)\end{array}$ & $\begin{array}{l}-11.23^{* * *} \\
(3.226)\end{array}$ & $\begin{array}{l}-0.140 \\
(1.317)\end{array}$ & $\begin{array}{l}-12.35^{* * *} \\
(3.209)\end{array}$ & $\begin{array}{l}0.358 \\
(1.501)\end{array}$ & $\begin{array}{l}-8.856^{* *} \\
(4.194)\end{array}$ \\
\hline No. of obs. & 635 & 635 & 635 & 635 & 635 & 635 \\
\hline No. of countries & 13 & 13 & 13 & 13 & 13 & 13 \\
\hline $\mathrm{CD}$ test $(\mathrm{p})$ & $-3.051(0.002)$ & $-3.408(0.001)$ & $-2.587(0.010)$ & $-3.085(0.002)$ & $-2.753(0.006)$ & $-3.544(0.000)$ \\
\hline
\end{tabular}


Table 14 - CCEMG-r and AMG Results for Developed Countries

\begin{tabular}{|c|c|c|c|c|c|c|}
\hline \multirow[t]{2}{*}{ Dep variable: GR } & \multicolumn{2}{|c|}{ Model 1} & \multicolumn{2}{|c|}{ Model 2} & \multicolumn{2}{|c|}{ Model 3} \\
\hline & CCEMG-r & AMG & CCEMG-r & AMG & CCEMG-r & AMG \\
\hline MAN & $\begin{array}{l}0.647^{* * * *} \\
(0.224)\end{array}$ & $\begin{array}{l}0.501^{* *} \\
(0.247)\end{array}$ & $\begin{array}{l}0.748^{* *} \\
(0.296)\end{array}$ & $\begin{array}{l}0.746^{* * *} \\
(0.218)\end{array}$ & $\begin{array}{l}0.773^{* *} \\
(0.365)\end{array}$ & $\begin{array}{l}0.763^{* * *} \\
(0.275)\end{array}$ \\
\hline $\mathrm{HC}$ & $\begin{array}{l}0.203 \\
(0.282)\end{array}$ & $\begin{array}{l}0.150 \\
(0.112)\end{array}$ & $\begin{array}{l}0.261 \\
(0.284)\end{array}$ & $\begin{array}{l}0.0313 \\
(0.0994)\end{array}$ & $\begin{array}{l}0.613 \\
(0.380)\end{array}$ & $\begin{array}{l}0.0320 \\
(0.138)\end{array}$ \\
\hline OPEN & $\begin{array}{l}-0.0417 \\
(0.0415)\end{array}$ & $\begin{array}{l}-0.0646 \\
(0.0446)\end{array}$ & $\begin{array}{c}-0.0818^{*} \\
(0.0455)\end{array}$ & $\begin{array}{c}-0.0884^{* *} \\
(0.0408)\end{array}$ & $\begin{array}{l}-0.0395 \\
(0.0454)\end{array}$ & $\begin{array}{c}-0.0672 \\
(0.0541)\end{array}$ \\
\hline RELUS & $\begin{array}{c}-0.579^{* * *} \\
(0.0973)\end{array}$ & $\begin{array}{l}-0.716^{* * *} \\
(0.0892)\end{array}$ & $\begin{array}{c}-0.663^{* * *} \\
(0.0552)\end{array}$ & $\begin{array}{l}-0.782^{* * *} \\
(0.103)\end{array}$ & $\begin{array}{l}-0.782^{* * *} \\
(0.167)\end{array}$ & $\begin{array}{l}-0.779^{* * *} \\
(0.115)\end{array}$ \\
\hline LNPOP & $\begin{array}{l}-0.148 \\
(0.295)\end{array}$ & $\begin{array}{c}-0.0228 \\
(0.146)\end{array}$ & $\begin{array}{l}0.0859 \\
(0.261)\end{array}$ & $\begin{array}{c}-0.212^{*} \\
(0.127)\end{array}$ & $\begin{array}{l}0.0266 \\
(0.298)\end{array}$ & $\begin{array}{l}-0.118 \\
(0.229)\end{array}$ \\
\hline $\mathrm{C}$ & & $\begin{array}{l}0.866^{* * *} \\
(0.0988)\end{array}$ & & $\begin{array}{l}0.890^{* * *} \\
(0.0946)\end{array}$ & & $\begin{array}{l}0.870 * * * \\
(0.0807)\end{array}$ \\
\hline SER & & & $\begin{array}{l}0.213 \\
(0.219)\end{array}$ & $\begin{array}{l}0.216 \\
(0.157)\end{array}$ & & \\
\hline FIR & & & & & $\begin{array}{l}0.325 \\
(0.435)\end{array}$ & $\begin{array}{l}0.669^{* * *} \\
(0.259)\end{array}$ \\
\hline TSC & & & & & $\begin{array}{l}-0.442 \\
(0.380)\end{array}$ & $\begin{array}{l}-0.173 \\
(0.355)\end{array}$ \\
\hline Intercept & $\begin{array}{l}-0.0982 \\
(0.937)\end{array}$ & $\begin{array}{l}-0.191 \\
(0.546)\end{array}$ & $\begin{array}{l}0.256 \\
(1.290)\end{array}$ & $\begin{array}{l}-0.237 \\
(0.713)\end{array}$ & $\begin{array}{l}0.342 \\
(1.617)\end{array}$ & $\begin{array}{l}-0.408 \\
(1.040)\end{array}$ \\
\hline No. of obs. & 635 & 635 & 635 & 635 & 635 & 635 \\
\hline No. of countries & 13 & 13 & 13 & 13 & 13 & 13 \\
\hline CD test $(p)$ & $-3.051(0.002)$ & $-1.834(0.067)$ & $-2.587(0.010)$ & $-2.147(0.032)$ & $-2.753(0.006)$ & $-2.383(0.017)$ \\
\hline
\end{tabular}


Table 15 - DCCE Results for Developed Countries

\begin{tabular}{|c|c|c|c|c|c|c|}
\hline Dep variable: GR & $\mathrm{Mo}$ & lel 1 & Mo & el 2 & Mo & el 3 \\
\hline & DCCEMG & DCCEP & DCCEMG & DCCEP & DCCEMG & DCCEP \\
\hline L_GR & $0.138^{* *}$ & $0.128^{* *}$ & $0.158^{* * *}$ & $0.149^{* * *}$ & $0.158^{* * *}$ & $0.141^{* *}$ \\
\hline & $(0.0672)$ & $(0.0521)$ & $(0.0609)$ & $(0.0541)$ & $(0.0568)$ & $(0.0555)$ \\
\hline MAN & 0.449 & 0.171 & $0.681^{*}$ & $0.524 * * *$ & 0.366 & $0.467^{* * *}$ \\
\hline & $(0.424)$ & $(0.113)$ & $(0.371)$ & $(0.133)$ & $(0.463)$ & $(0.152)$ \\
\hline $\mathrm{HC}$ & 0.175 & 0.0251 & 0.163 & 0.0505 & 0.218 & -0.00395 \\
\hline & $(0.337)$ & $(0.0473)$ & $(0.356)$ & $(0.0475)$ & $(0.420)$ & $(0.0636)$ \\
\hline OPEN & -0.0292 & 0.00389 & -0.0590 & -0.0136 & -0.0316 & 0.00591 \\
\hline & $(0.0409)$ & $(0.00948)$ & $(0.0528)$ & $(0.00979)$ & $(0.0606)$ & $(0.0124)$ \\
\hline RELUS & $-0.789^{* * *}$ & $-0.353 * * *$ & $-0.921^{* * *}$ & $-0.610^{* * *}$ & $-1.173^{* * *}$ & $-0.750 * * *$ \\
\hline & $(0.170)$ & $(0.0659)$ & $(0.165)$ & $(0.0816)$ & $(0.222)$ & $(0.0963)$ \\
\hline LNPOP & -0.289 & -0.0643 & -0.621 & -0.160 & -0.243 & $-0.339 * *$ \\
\hline & $(0.329)$ & $(0.106)$ & $(0.410)$ & $(0.114)$ & $(0.496)$ & $(0.171)$ \\
\hline SER & & & $0.478^{*}$ & $0.505^{* * *}$ & & \\
\hline & & & $(0.250)$ & $(0.128)$ & & \\
\hline FIR & & & & & $0.640^{*}$ & $0.704^{* * *}$ \\
\hline & & & & & $(0.346)$ & $(0.227)$ \\
\hline TSC & & & & & -0.0483 & 0.182 \\
\hline & & & & & $(0.702)$ & $(0.315)$ \\
\hline Intercept & 0.351 & $-10.76^{* *}$ & 0.00963 & -6.568 & -0.535 & 3.428 \\
\hline & $(2.273)$ & $(5.400)$ & $(3.325)$ & $(5.760)$ & $(1.823)$ & $(7.619)$ \\
\hline No. of obs. & 624 & 624 & 624 & 624 & 624 & 624 \\
\hline No. of countries & 13 & 13 & 13 & 13 & 13 & 13 \\
\hline CD test $(\mathrm{p})$ & $-2.058(0.040)$ & $-3.207(0.001)$ & $-1.672(0.095)$ & $-2.782(0.005)$ & $-1.675(0.094)$ & $-3.381(0.001)$ \\
\hline
\end{tabular}




\section{APPENDIX B - CCE Models Results for Developing Countries}

Considering the developing countries data, the $\mathrm{CD}$ tests results indicate only one specification without cross-sectionally dependent residuals, the AMG Model 1. Therefore, all but one model has dependent errors and may not control for the presence of common correlated effects.

Table 16 - CCEMG and CCEP Results for Developing Countries

\begin{tabular}{|c|c|c|c|c|c|c|}
\hline Dep variable: GR & $\mathrm{Mo}$ & el 1 & $\mathrm{Mo}$ & el 2 & Mo & el 3 \\
\hline & CCEMG & CCEP & CCEMG & CCEP & CCEMG & CCEP \\
\hline MAN & $\begin{array}{l}0.514^{* *} \\
(0.247)\end{array}$ & $\begin{array}{l}0.256^{* *} \\
(0.117)\end{array}$ & $\begin{array}{l}0.670^{* *} \\
(0.318)\end{array}$ & $\begin{array}{l}0.227^{*} \\
(0.126)\end{array}$ & $\begin{array}{l}0.633^{* *} \\
(0.256)\end{array}$ & $\begin{array}{l}0.251^{*} \\
(0.135)\end{array}$ \\
\hline $\mathrm{HC}$ & $\begin{array}{l}0.0815 \\
(0.228)\end{array}$ & $\begin{array}{l}-0.0723 \\
(0.0575)\end{array}$ & $\begin{array}{l}0.262 \\
(0.297)\end{array}$ & $\begin{array}{l}-0.0863 \\
(0.0616)\end{array}$ & $\begin{array}{l}0.128 \\
(0.287)\end{array}$ & $\begin{array}{l}-0.109 \\
(0.0743)\end{array}$ \\
\hline OPEN & $\begin{array}{l}0.126^{* *} \\
(0.0576)\end{array}$ & $\begin{array}{l}0.0699^{* * *} \\
(0.0245)\end{array}$ & $\begin{array}{l}0.107^{*} \\
(0.0566)\end{array}$ & $\begin{array}{l}0.0626^{* *} \\
(0.0255)\end{array}$ & $\begin{array}{l}0.169^{* * *} \\
(0.0588)\end{array}$ & $\begin{array}{l}0.0655^{* *} \\
(0.0280)\end{array}$ \\
\hline RELUS & $\begin{array}{l}-4.835^{* * *} \\
(0.936)\end{array}$ & $\begin{array}{l}-1.181^{* * *} \\
(0.104)\end{array}$ & $\begin{array}{l}-5.186^{* * *} \\
(1.111)\end{array}$ & $\begin{array}{l}-1.315^{* * *} \\
(0.111)\end{array}$ & $\begin{array}{l}-4.935^{* * *} \\
(1.218)\end{array}$ & $\begin{array}{l}-1.558^{* * *} \\
(0.127)\end{array}$ \\
\hline LNPOP & $\begin{array}{l}-0.195 \\
(0.417)\end{array}$ & $\begin{array}{c}-0.251^{*} \\
(0.131)\end{array}$ & $\begin{array}{l}-0.612 \\
(0.436)\end{array}$ & $\begin{array}{l}-0.360^{* *} \\
(0.150)\end{array}$ & $\begin{array}{l}-1.541^{* *} \\
(0.602)\end{array}$ & $\begin{array}{l}-0.484^{* * *} \\
(0.165)\end{array}$ \\
\hline SER & & & $\begin{array}{l}0.103 \\
(0.204)\end{array}$ & $\begin{array}{l}0.217^{* * *} \\
(0.0830)\end{array}$ & & \\
\hline FIR & & & & & $\begin{array}{l}0.450 \\
(0.407)\end{array}$ & $\begin{array}{l}0.440^{* *} \\
(0.193)\end{array}$ \\
\hline TSC & & & & & $\begin{array}{l}0.449 \\
(0.869)\end{array}$ & $\begin{array}{l}0.514^{*} \\
(0.309)\end{array}$ \\
\hline Intercept & $\begin{array}{l}0.733 \\
(1.709)\end{array}$ & $\begin{array}{l}0.557^{*} \\
(0.292)\end{array}$ & $\begin{array}{l}1.713 \\
(1.781)\end{array}$ & $\begin{array}{l}1.094^{* * *} \\
(0.391)\end{array}$ & $\begin{array}{l}3.795^{* *} \\
(1.829)\end{array}$ & $\begin{array}{l}0.394 \\
(0.431)\end{array}$ \\
\hline No. of obs. & 1339 & 1339 & 1339 & 1339 & 1339 & 1339 \\
\hline No. of countries & 28 & 28 & 28 & 28 & 28 & 28 \\
\hline CD test $(\mathrm{p})$ & $-2.894(0.004)$ & $-4.172(0.000)$ & $-2.783(0.005)$ & $-4.325(0.000)$ & $-2.364(0.018)$ & $-4.077(0.000)$ \\
\hline
\end{tabular}


Table 17 - CCEMG-r and AMG Results for Developing Countries

\begin{tabular}{|c|c|c|c|c|c|c|}
\hline \multirow[t]{2}{*}{ Dep variable: GR } & \multicolumn{2}{|c|}{ Model 1} & \multicolumn{2}{|c|}{ Model 2} & \multicolumn{2}{|c|}{ Model 3} \\
\hline & CCEMG-r & AMG & CCEMG-r & $\mathrm{AMG}$ & CCEMG-r & AMG \\
\hline MAN & $\begin{array}{l}0.544^{* *} \\
(0.231)\end{array}$ & $\begin{array}{l}0.288^{*} \\
(0.159)\end{array}$ & $\begin{array}{l}0.454^{* *} \\
(0.197)\end{array}$ & $\begin{array}{l}0.187 \\
(0.164)\end{array}$ & $\begin{array}{l}0.542^{* *} \\
(0.240)\end{array}$ & $\begin{array}{l}0.317^{*} \\
(0.191)\end{array}$ \\
\hline $\mathrm{HC}$ & $\begin{array}{l}0.0259 \\
(0.247)\end{array}$ & $\begin{array}{l}0.0596 \\
(0.109)\end{array}$ & $\begin{array}{l}-0.0884 \\
(0.259)\end{array}$ & $\begin{array}{l}-0.0297 \\
(0.126)\end{array}$ & $\begin{array}{l}-0.126 \\
(0.249)\end{array}$ & $\begin{array}{l}-0.0217 \\
(0.144)\end{array}$ \\
\hline OPEN & $\begin{array}{l}0.129 * * \\
(0.0567)\end{array}$ & $\begin{array}{l}0.0546 \\
(0.0413)\end{array}$ & $\begin{array}{l}0.103^{* *} \\
(0.0501)\end{array}$ & $\begin{array}{l}0.0374 \\
(0.0359)\end{array}$ & $\begin{array}{l}0.176^{* * *} \\
(0.0529)\end{array}$ & $\begin{array}{l}0.0557 \\
(0.0387)\end{array}$ \\
\hline RELUS & $\begin{array}{l}-3.197^{* * *} \\
(0.647)\end{array}$ & $\begin{array}{l}-2.168^{* * *} \\
(0.330)\end{array}$ & $\begin{array}{l}-2.977^{* * *} \\
(0.509)\end{array}$ & $\begin{array}{l}-2.011^{* * *} \\
(0.309)\end{array}$ & $\begin{array}{l}-2.114^{\text {*** }} \\
(0.293)\end{array}$ & $\begin{array}{l}-1.950^{* * *} \\
(0.336)\end{array}$ \\
\hline LNPOP & $\begin{array}{l}-0.438 \\
(0.399)\end{array}$ & $\begin{array}{l}-0.226 \\
(0.221)\end{array}$ & $\begin{array}{c}-0.776^{*} \\
(0.441)\end{array}$ & $\begin{array}{l}-0.379 \\
(0.247)\end{array}$ & $\begin{array}{c}-0.947^{*} \\
(0.528)\end{array}$ & $\begin{array}{l}-0.140 \\
(0.186)\end{array}$ \\
\hline $\mathrm{C}$ & & $\begin{array}{l}0.958^{* * *} \\
(0.124)\end{array}$ & & $\begin{array}{l}0.946^{* * *} \\
(0.132)\end{array}$ & & $\begin{array}{l}0.948^{* * *} \\
(0.127)\end{array}$ \\
\hline SER & & & $\begin{array}{l}0.185 \\
(0.162)\end{array}$ & $\begin{array}{l}0.0725 \\
(0.148)\end{array}$ & & \\
\hline FIR & & & & & $\begin{array}{l}0.598^{*} \\
(0.347)\end{array}$ & $\begin{array}{l}-0.232 \\
(0.282)\end{array}$ \\
\hline TSC & & & & & $\begin{array}{l}0.0336 \\
(0.229)\end{array}$ & $\begin{array}{l}0.0363 \\
(0.272)\end{array}$ \\
\hline Intercept & $\begin{array}{l}-0.521 \\
(1.453)\end{array}$ & $\begin{array}{l}0.302 \\
(0.747)\end{array}$ & $\begin{array}{l}0.854 \\
(1.741)\end{array}$ & $\begin{array}{l}0.413 \\
(0.898)\end{array}$ & $\begin{array}{l}3.906^{* *} \\
(1.937)\end{array}$ & $\begin{array}{l}-0.0307 \\
(0.624)\end{array}$ \\
\hline No. of obs. & 1339 & 1339 & 1339 & 1339 & 1339 & 1339 \\
\hline No. of countries & 28 & 28 & 28 & 28 & 28 & 28 \\
\hline CD test $(p)$ & $-2.894(0.004)$ & $-1.692(0.091)$ & $-2.783(0.005)$ & $-2.472(0.013)$ & $-2.364(0.018)$ & $-2.428(0.015)$ \\
\hline
\end{tabular}


Table 18 - DCCE Results for Developing Countries

\begin{tabular}{|c|c|c|c|c|c|c|}
\hline Dep variable: GR & Mo & lel 1 & $\mathrm{Mo}$ & el 2 & Mo & el 3 \\
\hline & DCCEMG & DCCEP & DCCEMG & DCCEP & DCCEMG & DCCEP \\
\hline L_GR & $0.232^{* * *}$ & $0.145^{* * *}$ & $0.252^{* * *}$ & $0.166^{* * *}$ & $0.262^{* * *}$ & $0.205^{* * *}$ \\
\hline & $(0.0516)$ & $(0.0314)$ & $(0.0560)$ & $(0.0329)$ & $(0.0591)$ & $(0.0353)$ \\
\hline MAN & 0.0682 & 0.148 & 0.159 & 0.215 & 0.122 & 0.275 \\
\hline & $(0.306)$ & $(0.154)$ & $(0.375)$ & $(0.164)$ & $(0.332)$ & $(0.183)$ \\
\hline $\mathrm{HC}$ & 0.179 & -0.0133 & -0.0104 & -0.0286 & -0.0577 & -0.0342 \\
\hline & $(0.489)$ & $(0.0796)$ & $(0.565)$ & $(0.0891)$ & $(0.562)$ & $(0.107)$ \\
\hline OPEN & $0.121^{* *}$ & $0.0491^{*}$ & $0.105^{*}$ & 0.0468 & $0.108^{* *}$ & 0.0478 \\
\hline & $(0.0500)$ & $(0.0288)$ & $(0.0598)$ & $(0.0303)$ & $(0.0518)$ & $(0.0334)$ \\
\hline RELUS & $-3.201^{* *}$ & $-1.708^{* * *}$ & $-3.685^{* * *}$ & $-1.913^{* * *}$ & $-4.067^{* *}$ & $-2.240 * * *$ \\
\hline & $(1.303)$ & $(0.137)$ & $(1.362)$ & $(0.150)$ & $(1.670)$ & $(0.175)$ \\
\hline LNPOP & -0.262 & -0.0439 & -0.845 & -0.151 & -1.255 & 0.00184 \\
\hline & $(0.658)$ & $(0.172)$ & $(0.639)$ & $(0.205)$ & $(0.992)$ & $(0.241)$ \\
\hline SER & & & 0.332 & $0.310^{* * *}$ & & \\
\hline & & & $(0.234)$ & $(0.112)$ & & \\
\hline FIR & & & & & 0.161 & $0.661^{* * *}$ \\
\hline & & & & & $(0.540)$ & $(0.249)$ \\
\hline TSC & & & & & 1.266 & $0.752^{*}$ \\
\hline & & & & & $(0.800)$ & $(0.395)$ \\
\hline Intercept & 0.0542 & 0.581 & 0.305 & $1.572^{* * *}$ & 0.544 & -0.568 \\
\hline & $(0.835)$ & $(0.445)$ & $(0.923)$ & $(0.551)$ & (1.168) & $(0.973)$ \\
\hline No. of obs. & 1320 & 1320 & 1320 & 1320 & 1320 & 1320 \\
\hline No. of countries & 28 & 28 & 28 & 28 & 28 & 28 \\
\hline CD test $(p)$ & $-2.130(0.033)$ & $-3.931(0.000)$ & $-2.672(0.008)$ & $-3.903(0.000)$ & $-2.191(0.028)$ & $-3.976(0.000)$ \\
\hline
\end{tabular}

